\title{
Working
}

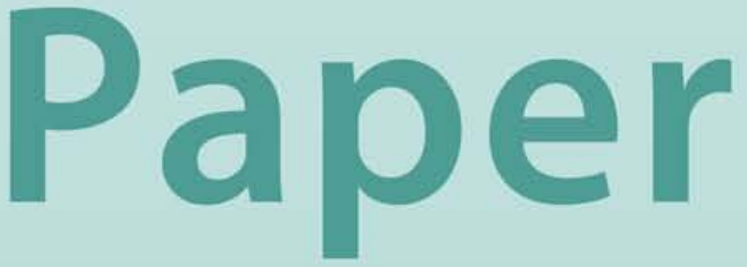


Globalization and Catching-Up: From Recession to Growth in Transition Economies

Grzegorz W. Kolodko 


\title{
IMF Working Paper
}

\author{
Research Department
}

\section{Globalization and Catching-Up: From Recession to Growth in Transition Economies}

\author{
Prepared by Grzegorz W. Kolodko ${ }^{1}$ \\ Authorized for distribution by Eduardo Borensztein
}

June 2000

\begin{abstract}
The views expressed in this Working Paper are those of the author(s) and do not necessarily represent those of the IMF or IMF policy. Working Papers describe research in progress by the author(s) and are published to elicit comments and to further debate.
\end{abstract}

The transitional recession in countries of Eastern Europe and the Former Soviet Union has lasted much longer than expected. The legacy of the past and recent policy mistakes have both contributed to the slow progress. As structural reforms and gradual institution building have taken hold, the post-socialist economies have started to recover, with some leading countries building momentum toward faster growth. There is a possibility that in the wider context of globalization several of these emerging market economies will be able to catch up with the more advanced industrial economies in a matter of one or two generations.

JEL Classification Numbers:E37, F43, N10, O47, P24, P27

Keywords: Globalization, transition, institution-building, recession, growth

Author's E-Mail Address: kolodko@prodigy.net

\footnotetext{
${ }^{1}$ This paper was written when the author was a Visiting Scholar in the Research Department and the Fiscal Affairs Department of the IMF. Mr. Grzegorz W. Kolodko-professor at Warsaw School of Economics and Visiting Professor at the University of Rochester and UCLA--was Poland's Deputy Premier and Finance Minister in 1994-97. The views presented in this paper are the author's alone and should not be taken as representative of the $\mathrm{IMF}$ or the Polish government, or any other organization the author may be associated with.
} 


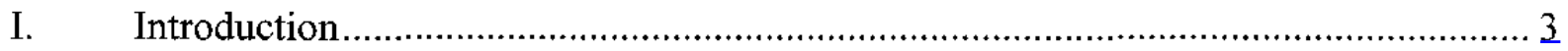

II. Globalization and Post-socialist Transformation........................................... 4

III. Transitional Recession and the Great Depression of the 1990s............................... 6

IV. Different Paths of Contraction, Recovery and Growth.......................................... 13

V. Policy Response and the Role of Institution-building ........................................ 18

VI. External Shocks and the Catching-up Process ............................................... 22

VII. Four Scenarios for Long-term Growth until 2050 .......................................... 26

VIII. Active Policies for Catching-up in the $21^{\text {st }}$ Century ........................................... 38

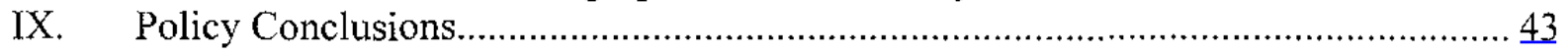

Tables:

1. Economic Growth Cycles in Centrally Planned Economies, $1950-89$..................... 8

2. Average Rate of Growth (NMP) in the Centrally Planned Economies, 1950-89 .........

3. Recession and Growth in Transition Economies: Rates of GDP Change, 1989-99 ...10

4. Transition Countries: Duration of Recession and Growth in 1990-99 ......................14

5. Transition Countries: Real GDP Index--Forecast for 2003-04 (1989=100 and

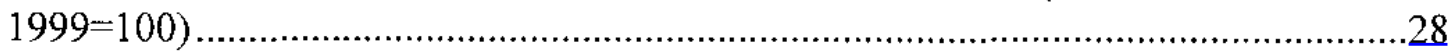

6. Transition Countries: GDP Per Capita in 1999 and 2003-04, PPP Basis ................29

7. Transition Economies: Average Rate of GDP Growth in 2000-03(4) .......................32

8. Catching-up in the Transition Economies in the $21^{\text {st }}$ Century, 2000-2050 ................35

9. Transition Countries:The Year of Catching-up with the Developed Countries .........44

Figures:

1. Transition Countries: Index of Aggregated GDP for the Decade

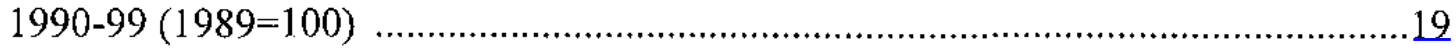

2. Alternative Growth Paths for the Very Long-term, 2000-2050 ..............................34

3. Catching-up with the Developed Countries ..................................................

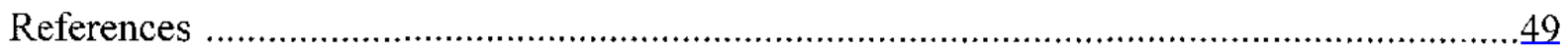




\section{INTRODUCTION}

The historic endeavor of transforming the statist-controlled economies of Eastern Europe (EE) and the former Soviet Union (FSU) from a system of central planning to the institutional arrangements of a free market economy is an unparalleled undertaking. The ongoing transition taking place in the former centrally planned economies of Eastern Europe (EE) and the former Soviet Union (FSU), some 25 countries is indispensable part of today's globalization. Without this transition globalization would fall short of its full dimension and dynamism. ${ }^{2}$

Leaving aside the political and ideological concerns of such a fundamental change, the main argument in favor of moving to a market system was a wide conviction that the introduction of a market economy would improve competitiveness and efficiency in the former Centrally Planned Economies (CPEs). It was expected that after some short period of transitional contraction the new system should lead to recovery and later to fast growth. However, for a number of reasons these goals have not occurred.

The transitional recession lasted much longer than expected, contraction was deeper than assumed earlier, and the recovery was not--and in several cases still is not-as smooth as envisaged both by the relevant governments and the concerned international organizations. Actually, instead of rapid recovery and robust growth, the protracted recession turned out to be a Great Transitional Depression, continuing in some countries over the whole decade of the 1990s. Moreover, it is important to observe that this great depression took effect to the full extent in two of the largest transition economies, i.e., Russia and Ukraine, with a combined population of about 200 million, or half of the population of all the countries in transition.

While after the first decade of transition, i.e., 1990-99, the index of average (weighted) GDP for the 25 countries of EE and FSU stands at around 65 percent of pretransition output, it went as low as 54 percent for the FSU economies, and in the case of the EE economies it is still below the 1989 level. This output decline was not expected at the onset of the transition process. Furthermore, the surprise stemming from these unforeseen developments caused significant differences in the interpretations of occurring events. This holds true with respect to the explanations of the causes of the lengthy contraction as well as the sources of fast growth in the countries where it has happened. Thus it is worthwhile to look for patterns of underlying roots of these processes in transition economies, especially from the standpoint of policy options for the future and their political and technical constraints.

\footnotetext{
${ }^{2}$ The EE countries comprise of Albania, Bosnia-Herzegovina, Bulgaria, Croatia, Czech Republic, Hungary, Poland, FRY Macedonia, Romania, Slovakia, Slovenia, and Yugoslavia. The FSU countries comprise of Armenia, Azerbaijan, Belarus, Estonia, Georgia, Kazakhstan, Kyrgyzstan, Latvia, Lithuania, Moldova, Russia, Tajikistan, Turkmenistan, Ukraine, and Uzbekistan.
} 
Consequently, after the introduction, Section II briefly discusses the links and feedback between globalization and transition to a market economy. In Section III the scope and dynamism as well as the general causes of deep transitional recession are presented. Section IV describes various paths of recession, recovery and growth, because these processes have evolved along quite different routes in particular countries and regions of the $\mathrm{EE}$ and FSU. Section V elaborates on policy responses towards the challenge of prolonged transitional depression, while especially stressing the meaning of institutional vacuum and the importance of institution-building. In Section VI the implications of globalization and external shocks for recovery and growth are discussed as well as the chances and mechanisms of catching-up with highly-developed industrial economies. Section VII presents alternative growth paths and long-term passive scenarios out to the year 2050. Section VIII examines the active policies options and provides some advice aiming at the acceleration of growth and its sustainability in the long-term. Finally, in Section IX, policy conclusions are presented for the further debate.

\section{Globalization And Post-Socialist Transformation}

The last decade of the $20^{\text {th }}$ century has been marked by immense changes in the world economy. The new phase of the technological revolution and the far-reaching internationalization of capital flows have changed the patterns of economic performance. Broad trade liberalization, accompanied by growing liberalization of financial and capital markets, has brought about new prospects and new challenges. These challenges must be tackled not only by the governments and various international organizations, but to a growing extent by the private sector and nongovernmental organizations (NGOs). Hence, on the eve of the new century, there are not only mounting old structural problems, but several new issues that must be addressed properly by theoretical considerations and particularly by sound policy responses.

First, the private sector ought not to be the main beneficiary of the fruits of globalization and transition, but must be engaged more than it has so far in crisis management. The role of private business is growing worldwide, both in advanced market economies and in developing and formerly centrally planned economies-in the latter mainly owing to vast privatization program. Hence, the private sector must bear a larger responsibility for the outcomes of the crises, when they hit. The private sector in advanced industrial countries - including various financial intermediaries, investment banks, hedge funds, and multinational corporations - while becoming more involved in business on a global scale, must also be more concerned about sharing the responsibility and the costs when the international flow of capital fails to deliver positive results.

Second, the international organizations-including regional development banks and institutions dealing with particular aspects of international and global economic activities (i.e., International Monetary Fund (IMF), World Bank (WB), World Trade Organization (WTO), United Nations Trade and Development (UNCTAD), International Labor Organization (ILO), etc.) - must coordinate their actions in a well-orchestrated way. Despite advancing liberalization, or in some sense because of it, there are certain intertwined 
processes monitored by different organizations, yet the latter are not capable of coordinating their policies in a sufficient way. Many problems on the global economic scene, including the post-socialist theatre, have evolved because of the lack of such coordination. A good example here is too risky exposition for an unregulated flow of short-term capital, which may help facilitate economic growth in emerging markets, but may also make growth more difficult. Unfortunately, in recent years the latter was often the case. If the risk evolving from too rapid trade liberalization is augmented by the risk coming from radical financial liberalization, then these risks escalate critically, particularly in economies with weak institutions. This is often the case in emerging markets, especially in the post-socialist countries.

Third, the international NGOs are going to play a much more important role than they have thus far. They must be seen as a strategic partner for the private sector, governments and their international organizations. The recent case of coordinating the actions regarding debt reduction for heavily-indebted poor countries (HIPCs) is a good example of such work and may turn out to be a good model for the future. If the leading developed countries from the G-7 group, as well as the IMF and WB work out the challenge of sharing the debt burden with certain NGOs, like Oxfam and Jubilee 2000, then the effects would likely be visible. The future will definitely hold more initiatives of similar character, in particular investment in human capital and environmental protection, on the one hand, and programs to counteract poverty and inequality, on the other. Transition economies will also be increasingly involved in these types of endeavors, which will enhance their ability to develop faster, since these activities are linked to the learning process and encourage more favorable participation in the global economic interchange.

Fourth, the systemic transition to a market economy has per se significant meaning for globalization. Some of the transition countries are clearly on the path toward a fullfledged market economy, while others, are still attempting to reform their existing economic systems, e.g., China, and will most likely join this process soon. All three aspects of transition, that is liberalization-cum-stabilization, institution-building, and the restructuring of industrial capacity, are related to the process of integrating individual economies into a global international monetary and economic system (Kolodko, 1992b).

Liberalization-cum-stabilization is linked to the process of opening up economies that were previously relatively closed. This is reflected not only in the fact that, due to higher participation by the countries in transition in the international division of labor, their imports and exports are growing faster (or, during contraction, falling slower) than the countries overall output. This also means free entry to and exit from liberally-regulated businesses of both domestic and international entrepreneurs. Additionally, capital flows have been liberalized enabling the infant capital markets of these countries to rapidly enter and participate in the global financial and capital markets. International investors are particularly active in the financial and utilities sectors. This penetration not only improves the quality of services provided by these sectors, but also creates a risk of "dependent capitalism" (Poznanski, 1997). Such risk stems from the asymmetry between the scope of capital being invested by transnational corporations and foreign investors in these countries, and is exacerbated by scarce investment capital these countries have to invest in foreign markets, 
especially since they are even short of capital to meet their own needs. This challenge can be overcome only in the long run, provided that financial stabilization is accomplished, the fundamentals are sound, and growth is fast.

Institution-building, especially through new laws and organizations that facilitate market-based allocation of resources, is linked to globalization too. There are several institutional arrangements, which at the same time are a part of the international and global institutional order, e.g., regulation vis-à-vis trade liberalization agreed within the framework of the WTO, or standards and policies aiming at protection of natural resources and the environment. An indispensable part of globalization is the process of regional integration, e.g., with (and later within) the European Union and, after the initial disintegration, within the FSU. During globalization the national economies' institutional arrangements are becoming more similar; the more in-line they become, the easier is the process of integration and globalization.

All these reforms lead to microeconomic restructuring of the existing industrial capacity (Lavigne, 1999). To a large degree this restructuring takes place simultaneously with the expanding involvement of multinational corporations. Thus a growing proportion of the production and distribution processes in transition economies can be seen as a fraction of the global economy. Increasing inward foreign direct investments (FDI) are contributing importantly to this process. Nonetheless, it is crucial for future growth that transition countries achieve a higher propensity to save than has been the case so far; this in turn would enhance their capacity to build domestic capital formation (Kolodko, 1999b).

From this perspective, a sustained inflow of FDI must be seen only as an addition to the healthy flow of domestic capital. Owing to globalization FDI should continue, even after the privatization process, which attracted so much of the growing inward FDI flows in the $1990 \mathrm{~s}$, has been completed. Hence it should be expected that future FDI will also be targeting at microeconomic restructuring and will contribute to rising competitiveness in the long run. All these investment efforts ought to enhance growth in the transition economies even further.

\section{Transitional RECESSION AND THE GREAT DEPRESSION OF THE 1990S}

Before the historic endeavor to transform the former centrally planned economies into market economies was launched, these economies were growing. Indeed, they were growing fast. Over the four decades preceding the 1990 s the annual rate of growth averaged from 4.8 percent in the former Czechoslovakia to 8.2 percent in Romania. ${ }^{3}$ With such a pace of growth the national income had doubled in 16 years in the former case, and in less than nine

${ }^{3}$ There should be doubts about the reliability of data from this period. Even with certain errors, long-term analyses and comparisons between particular countries should be possible. However, the conclusions drawn from these analyses should be treated with caution, and they are in this paper. 
years in the latter case. However, growth under the centrally planned system had numerous specific features. At least five of them are worth mentioning in the context of the way of reasoning relevant in these considerations.

First, despite stubborn attempts by the governments-or indeed quite often because of their intervention in economic matters and owing to the bureaucratic allocation of resources-there were specific growth cycles (Bauer, 1978; Kolodko, 1976). Although output was growing systematically, the medium-term rate of growth fluctuated. There were periods of accelerated growth, and then periods of correction, during which growth slowed down. Later, another expansion was launched and the sequence, by and large, was repeated (Table 1). These two features, that is, the endogenous mechanism of periodic fluctuation and the relatively regular character of these changes - justify the interpretation of those processes as being of a cyclical nature.

Second, growth in the former CPEs was of a "bad quality." Even in the relatively better performing economies the shortage syndrome was never entirely eliminated. Continuing shortages were causing serious economic and political stress. Price distortions led to additional obstacles to sustaining a high and stable rate of growth. At the later stage, in some countries the shortages were accompanied by open (i.e., price/wage) inflation; thus the so-called "shortageflation" syndrome emerged (Kolodko and McMahon, 1987). Consequently, growth was associated with lasting disequilibrium. Under the central planning allocation system this outcome was opposite to what authorities expected.

Third, despite a high rate of growth the living standard in the region was not improving fast enough. The socialist (communist) model of development was based on expansion of heavy industries and an investment drive, with consumption growing at an always slower rate. Owing to the cyclical nature of growth, the rate of consumption growth fluctuated too, yet the highest variation was vis-à-vis investments. Nevertheless, (at least from the perspective of people's expectations) improvement in the standard of living was too slow and was causing increasing social dissatisfaction, which in turn led to a further loss of momentum. This factor, together with the discomfort of shortageflation, explains why the socio-political system of the CPEs got out of balance despite a not that low rate of overall production growth.

Fourth, there was a "growth fatigue" (Poznanski, 1996) under central planning. The pace of growth was slowing, especially at the later stages. After an initial period of rapid growth in the 1950s and $1960 \mathrm{~s}$, the rate of growth declined significantly, even though investments were growing faster than overall production, which shows that efficiency was disintegrating. As labor productivity was growing still slower, in the late 1980 s growth came close to stagnation, and in 1989 it turned sluggish. Thus the potential for economic growth was fading away. Later, unfortunately, together with the beginning of transition, the recession had started and inflation accelerated significantly. Thus these countries, although to different degrees and for different periods of time, had shifted from one malaise -shortageflation under a dying centrally planned regime to another, "slumpflation" under the emerging market order (Kolodko, 1992a). 
Table 1. Economic Growth Cycles in Centrally Planned Economies, 1950-89 Years/Growth Rate in Net Material Product

(In percent)

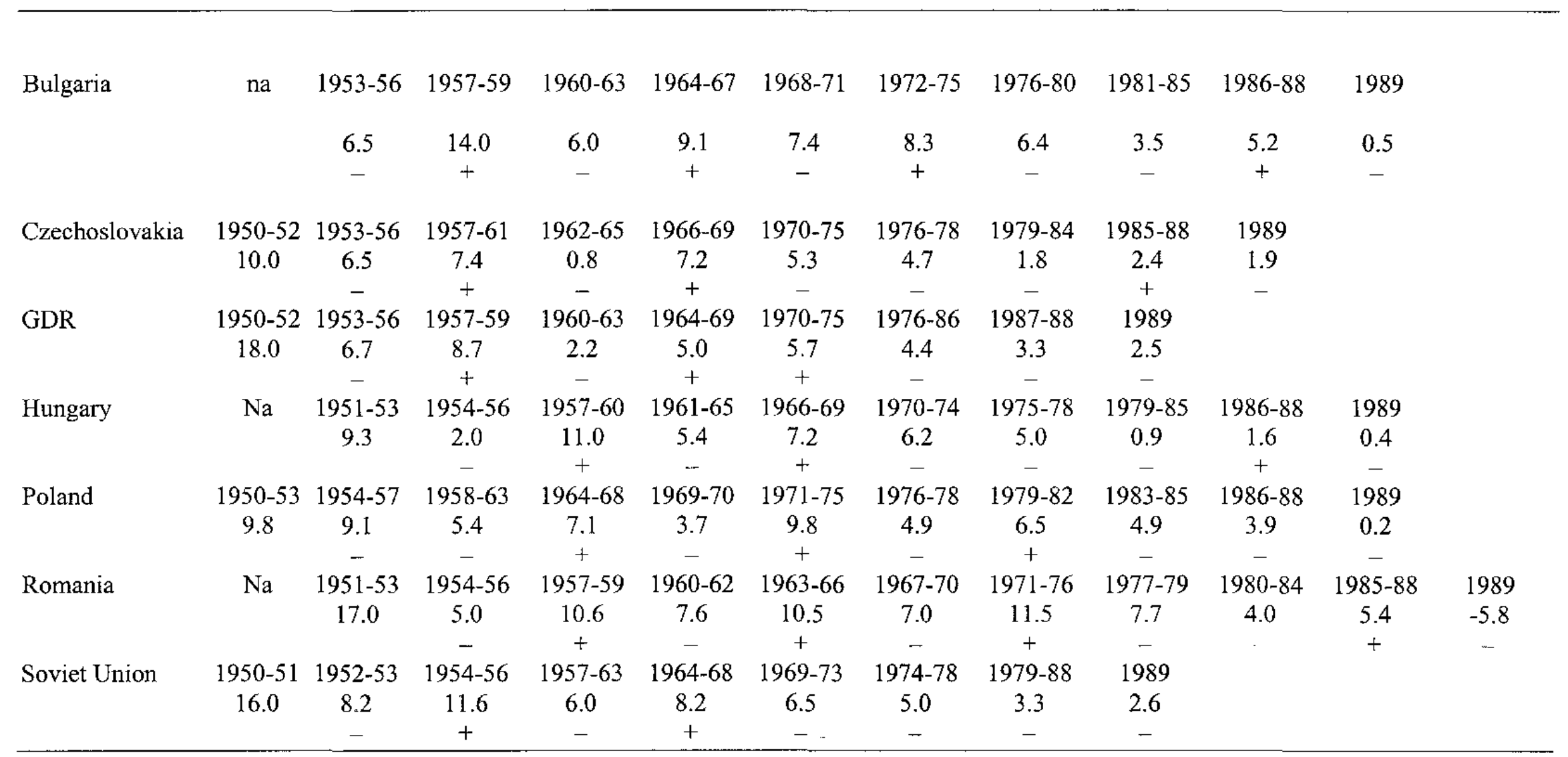

Sources: Central Statistical Office (GUS), Warsaw, various years, and author's calculations.

'+' - acceleration. '-' - slowdown. 
Fifth, the catching-up process was already taking place under the centrally planned system. Especially in the early years, the CPEs at a relatively lower level of development, e.g., Bulgaria and Romania, were growing much faster than the countries enjoying a relatively higher level of production and hence a better standard of living, e.g., Hungary and the former Czechoslovakia (Table 2). The same can be said about the pattern of growth in the former Soviet Union, where the Caucasus and Central Asian republics were growing significantly faster than the East European republics. Though to a lesser extent the situation in the former Yugoslavian republics was similar, where, for instance, the rate of growth in Macedonia was higher than in Slovenia.

Table 2: Average Rate of Growth (NMP) in the Centrally Planned Economies, 1950-89

(In percent)

\begin{tabular}{lccc}
\hline & First Phase & $\begin{array}{c}\text { Last Phase } \\
\text { of } \\
\text { of }\end{array}$ \\
\hline Romania** & 8.2 & 17.0 & 5.4 \\
Bulgaria* $_{\text {Poland }}$ & 6.9 & $>10.0$ & 5.2 \\
Soviet Union & 6.7 & 9.8 & 3.9 \\
GDR & 6.5 & 16.0 & 3.3 \\
Hungary** & 5.9 & 18.0 & 3.3 \\
Czechoslovakia & 5.0 & 9.3 & 1.6 \\
\hline
\end{tabular}

Sources: Central Statistical Office (GUS), Warsaw, various years and author's calculations.

* Average for 1953-89

** Average for 1951-89

NMP - Net Material Product

And then the transition recession began. It lasted for three years in the best casei.e., Poland from mid-1989 until mid-1992 - to as many as ten years in the worst case, i.e., in Ukraine from 1990 until 1999. In the former, GDP contracted by about 20 percent before starting to recover and grow. In the latter country, output fell by over 60 percent and only started to grow in 2000. While only three countries-in addition to Poland in 1996, Slovenia in 1998 and Slovakia in 1999 - have been able to recover their pre-transitional levels of output, at the other end of the specter are countries doing even worse than Ukraine. In Georgia and Moldova GDP in 1999 was about one third of its 1989 level, and in another four FSU republics it was significantly below half that amount. Among the EE economies, in six countries GDP was hovering around or below three-fourths of the 1989 output level (Table 3). 
Table 3. Recession and Growth in Transition Economies: Rates of GDP Change, 1989-99

(In percent)

\begin{tabular}{|c|c|c|c|c|c|c|c|c|c|c|c|c|}
\hline & 1989 & 1990 & 1991 & 1992 & 1993 & 1994 & 1995 & 1996 & 1997 & 1998 & 1999 & $\begin{array}{c}\text { Real GDP } \\
1999 \\
1989=100\end{array}$ \\
\hline Poland & 0.2 & -11.6 & -7.0 & 2.6 & 3.8 & 5.2 & 7.0 & 6.1 & 6.9 & 4.8 & 3.8 & 121.6 \\
\hline Slovenia & -1.8 & -4.7 & -8.9 & -5.5 & 2.8 & 5.3 & 4.1 & 3.5 & 4.6 & 3.9 & 3.5 & 107.6 \\
\hline Slovakia & 1.4 & -2.5 & -14.6 & -6.5 & -3.7 & 4.9 & 6.9 & 6.6 & 6.5 & 4.4 & 1.9 & 101.5 \\
\hline Hungary & 0.7 & -3.5 & -11.9 & -3.1 & -0.6 & 2.9 & 1.5 & 1.3 & 4.6 & 5.1 & 4.2 & 99.2 \\
\hline Czech Republic & 1.4 & -1.2 & -11.5 & -3.3 & 0.6 & 3.2 & 6.4 & 3.8 & 0.3 & -2.3 & -0.3 & 94.7 \\
\hline Albania & 9.8 & -10.0 & -27.7 & -7.2 & 9.6 & 9.4 & 8.9 & 9.1 & -7.0 & 8.0 & 7.1 & 92.5 \\
\hline Uzbekistan & 3.7 & 1.6 & -0.5 & -11.1 & -2.3 & -4.2 & -0.9 & 1.6 & 2.4 & 3.3 & 3.0 & 92.3 \\
\hline Belarus & 8.0 & -3.0 & -1.2 & -9.6 & -7.6 & -12.6 & -10.4 & 2.8 & 10.4 & 8.3 & 1.5 & 78.2 \\
\hline Croatia & -1.6 & -7.1 & -21.1 & -11.7 & -8.0 & 5.9 & 6.8 & 6.0 & 6.5 & 2.3 & -0.7 & 77.2 \\
\hline Estonia & -1.1 & -8.1 & -13.6 & -14.2 & -9.0 & -2.0 & 4.3 & 3.9 & 10.6 & 4.0 & 0.0 & 75.7 \\
\hline Romania & -5.8 & -5.6 & -12.9 & -8.8 & 1.5 & 3.9 & 7.1 & 4.1 & -6.9 & -7.3 & -4.1 & 73.0 \\
\hline FYR Macedonia & 0.9 & -9.9 & -7.0 & -8.0 & -9.1 & -1.8 & -1.2 & 0.8 & 1.5 & 2.9 & 0.6 & 72.0 \\
\hline Bulgaria & 0.5 & -9.1 & -11.7 & -7.3 & -1.5 & 1.8 & 2.1 & -10.1 & -7.0 & 3.5 & 1.4 & 66.8 \\
\hline Lithuania & 1.5 & -5.0 & -6.2 & -21.3 & -16.0 & -9.5 & 3.5 & 4.9 & 7.4 & 5.2 & 0.0 & 65.4 \\
\hline Kyrgyzstan & 4.0 & 3.0 & -5.0 & -19.0 & -16.0 & -20.0 & -5.4 & 7.1 & 9.9 & 1.8 & 0.0 & 60.4 \\
\hline Kazakhstan & -0.4 & -0.4 & -13.0 & -2.9 & -9.2 & -12.6 & -8.2 & 0.5 & 2.0 & -2.5 & -1.7 & 60.2 \\
\hline Latvia & 6.8 & 2.9 & -10.4 & -34.9 & -14.9 & 0.6 & -0.8 & 3.3 & 8.6 & 3.6 & 1.5 & 60.1 \\
\hline Russia & 2.6 & -4.0 & -5.0 & -14.5 & -8.7 & -12.7 & -4.1 & -3.5 & 0.8 & -4.6 & 1.5 & 56.1 \\
\hline Turkmenistan & -6.9 & 2.0 & -4.7 & -5.3 & -10.0 & -18.8 & -8.2 & -8.0 & -26.1 & 4.2 & 17.0 & 51.2 \\
\hline Azerbaijan & -4.4 & -11.7 & -0.7 & -22.6 & -23.1 & -19.7 & -11.8 & 1.3 & 5.8 & 10.1 & 3.7 & 45.2 \\
\hline Tajikistan & -2.9 & -1.6 & -7.1 & -29.0 & -11.0 & -18.9 & -12.5 & -4.4 & 1.7 & 5.3 & 5.0 & 44.1 \\
\hline Armenia & 14.2 & -7.4 & -17.1 & -52.6 & -14.8 & 5.4 & 6.9 & 5.8 & 3.1 & 7.2 & 4.0 & 42.5 \\
\hline Ukraine & 4.0 & -3.4 & -11.6 & -13.7 & -14.2 & -23.0 & -12.2 & -10.0 & -3.2 & -1.7 & -2.5 & 35.7 \\
\hline Georgia & -4.8 & -12.4 & -20.6 & -44.8 & -25.4 & -11.4 & 2.4 & 10.5 & 11.0 & 2.9 & 3.0 & 33.8 \\
\hline Moldova & 8.5 & -2.4 & -17.5 & -29.1 & -1.2 & -31.2 & -3.0 & -8.0 & 1.3 & -8.6 & -5.0 & 30.5 \\
\hline Bosnia-Herzegovina & na & na & na & na & na & na & -5.7 & 58.9 & 50.1 & 19.4 & 6.6 & $\mathrm{x}$ \\
\hline Yugoslavia & na & na & na & na & na & 2.5 & 6.1 & 5.8 & 7.6 & 1.5 & -37.3 & $\mathrm{x}$ \\
\hline \multicolumn{13}{|c|}{ GDP-weighted average* } \\
\hline EE-13 & -0.2 & -6.6 & -10.7 & -3.6 & 0.4 & 3.9 & 5.5 & 4.0 & 3.6 & 2.4 & 1.7 & 99.3 \\
\hline CIS- 12 & 0.6 & -3.7 & -6.0 & -14.2 & -9.3 & -13.8 & -5.2 & -3.5 & 0.9 & -3.5 & 0.3 & 54.3 \\
\hline $\mathrm{EE}$ and FSU-25 & 0.3 & -5.0 & -8.1 & -9.5 & -5.0 & -6.0 & -0.5 & -0.2 & 2.0 & -1.2 & 1.0 & 71.3 \\
\hline
\end{tabular}

Sources: EBRD, 1999. Data for Russia for 1989 is from the Soviet Union; Sources as in Table 1. Preliminary data and forecast for 1999 also from PlanEcon, 1999a and 1999b, and from available national statistics. Data for BosniaHerzegovina and for Yugoslavia from PlanEcon, 1999b.

*The weights used are the EBRD estimates of nominal dollar-GDP for 1996.

na-data not available. 
Thus the great slump is a fact. However, it must be remembered that data for the transition economies is far from perfect. Of great significance here is the bias stemming from the existence of a vast informal sector, i.e., neither officially registered nor taxed. The issue is that informal activities alter upward both output and employment, but do not necessarily raise the rate of growth, or mitigate the rate of contraction. In another words, it is obvious that in transition economies the actual output and thus GDP is significantly higher than officially acknowledged in the range between 15 percent and 30 percent. However, this changes only the basis from which the pace of growth should be measured, not the rate of growth as such. Accordingly, at present both the overall GDP as well as the GDP per capita (and consequently the GDP absorption rate, i.e., private consumption and investment) are higher than may be suggested by the official data. The reason is not a faster than officially registered growth, but higher output at the point of departure. Hence these observations may change the understanding and interpretation of the absolute level of output, but not the pace of its expansion.

It must also be admitted that in some cases the range of the output fall at the onset of transition was exaggerated. Part of actual production did not vanish, but was transferred, most oflen together with assets, from the official to the informal sector. Later this particular form of privatization (since the official sector used to be state-owned and the unofficial became a privately-owned) resulted in a faster officially registered pace of growth than was actually occurring. Output, which existed before but was not reported, turned out to be registered gradually and thus was counted in the official statistics.

Therefore the phenomenon of informal sector brings two types of bias to the real picture of the initial contraction and subsequent recovery. The real scope of the contraction could have been exaggerated, but so could real growth later on. Interestingly, in many analyses much more attention has been given to the former case than to the latter. The point is that in the longer run-say, in a period of a decade or two-the balance of these two contradictory phenomena may become neutral.

There was always a belief that growth would come sooner than it actually occurred. For instance, in Poland, at the beginning of transition, the government assumed that contraction would last just one year and the fall of GDP would not exceed 3.1 percent. Actually it lasted for three years and was six times more severe. Gomulka (1990) predicted a rate of growth of 4.7 percent, 8.7 percent and 7.9 percent for GDP in 1991-93. Whereas it should have brought about a sound expansion of about 22 percent over these three years, the Poland's economy actually contracted by 12 percent in 1990 and a further

7.0 percent in 1991. Only then did it grow by 2.6 percent and 3.8 percent in 1992-93. Assuming better policy response, for Hungary and Poland, Borensztein and Montiel (1991) foresaw an average 6.5 percent rate of growth in 1991-95 and 3.25 percent for the former Czechoslovakia. Summers (1992) expected the Polish economy to have turned around by 1991 ( 2 percent growth) and thereafter to soar by 5 to 6 percent. He had foreseen positive growth in the cases of Hungary, Poland, Romania, and Yugoslavia after 1992, and in the case of Bulgaria and Czechoslovakia after 1993, with the acceleration of a non-weighted mean rate of growth for the whole EE going up from 0.8 percent in 1992 to about 4 percent by the 
end of the decade. On the contrary, growth shrank by an additional 3.6 percent in 1992 (after a drop of about 17 percent in 1990-91) and at the end of decade it was expanding by a mere 2 percent.

Not only were the individual experts wrong, but so were the governments and respected international organizations. The International Monetary Fund in its World Economic Outlook 1991 expected GDP growth for EE to take place from 1992. After predicting a contraction of only 1.5 percent in 1991 (contrary to an actual collapse of 10.7 percent) GDP growth was forecast at 2.8 percent for 1992 and at 4.4 percent for 1993 (IMF, 1991), yet it dropped in the former year by 3.6 percent and then increased by just 0.4 percent in the subsequent year.

Then the pendulum of expectations shifted to the other extreme. In the October 1992 issue of World Economic Outlook - under the influence of data showing a severe contraction in 1991-the forecast was changed significantly. For the EE countries, instead of the earlier expectations of 2.8 percent growth in 1992, the forecast was for a 9.7 percent recession. As for the FSU economies, the forecast for that year was minus 18.2 percent, although the GDP actually contracted by "only" 14.2 percent.

There were a number of reasons why the early forecasts were too optimistic and expectations were not met. During the early transition period the range of uncertainty was huge, hence it was not difficult to be wrong simply because of the enormity of the process. Yet the true mistakes were more vis-à-vis the policies and their theoretical foundations than about the forecasts themselves. The latter were not accurate because the former were wrong (Kolodko, 1991 and 1999d; Nuti, 1992; Poznanski, 1996; and Stiglitz, 1999). Thus what has caused such a deep contraction that in so many cases turned out to be a decade-long depression of economic activity?

It is impossible to explain the Great Transitional Depression of 1990-99 exclusively by the legacy of the past or by the external shocks (Mundell, 1997). These factors, of course, play a meaningful role, however they should not be blamed as having primary responsibility for the misfortune of losing about half of the regions GDP over just one decade. The crucial role in these events was by policy decisions that often went wrong. Among the weakest areas of the adjustment programs was the negligence of institution-building of the market system. Performance of an emerging market economy depends more on the institutional arrangements than on overall economic liberalization.

Therefore, the discussion on the platform, "too fast versus too slow" liberalization and privatization has been led along wrong alternative lines (Kolodko and Nuti, 1997; and Stiglitz, 1998). The theoretical question and pragmatic challenge were not about the pace of either liberalization or privatization, but about the ways these two processes have been designed and coordinated (or, more precisely, often not coordinated) with institution- 
building. ${ }^{4}$ If the institution-building was not enhancing the former processes, then there was a lack of compatibility between the elements of the multi-track process of transition. As a result, instead of growing, the microeconomic efficiency was eroding still further, which in turn led to output falling for so long and so deeply.

\section{Different Paths of Contraction, Recovery and Growth}

Although indirect, there is one further argument proving that the legacy of the past, and bad or good luck, were not of critical importance to the transitional recession and growth, but rather how adjustment policies were executed. Past legacies may sometimes help, but in the post-socialist economies more often they hindered growth. Yet whatever that legacy is, the deciding factor is how policies are implemented. The argument is that, despite many structural, institutional, geopolitical and cultural similarities between these countries, they have been moving along very different paths over the first decade of transition (EBRD, 1999; Kolodko, 2000a, Blejer and Skreb, 2000). These paths have been (and will be) shaped more by policies than any other factor. This is the main cause why in certain countries the transitional recession lasted for three to five years, but in others it continued over the entire decade of the 1990s. Therefore the current level of output is a function of two occurrences. First, it is the result of the seriousness of the output decline in particular years of the recession. Second, it is the consequence of the number of years in recession.

In some countries, the contraction lasted for a relatively short period, yet the recession was altogether deeper owing to a more severe fall of output during that time. In other countries, the recession lasted for a longer period, but was milder because production dropped to a lesser extent in those years. In two countries most affected by the Great Transitional Depression--Moldova and Georgia - in 1999 GDP stood at about one third of the pre-transition level. Whereas it is the outcome of eight years of contraction and two years of growth in the former case, in the latter it is the result of six years of contraction and four years of growth. Countries, like Armenia, suffered recession only for a period of four years, yet that was enough to bring their national income down to about 40 percent of the country's pre-transition level. There are also countries like Romania, where output had been falling for seven years, but in 1999 it stood at 76 percent of the 1989 level (Table 4).

Transition is a unique process by its very nature and substance, even more so is the transitional recession, depression and recovery. There are extreme examples of annual declines of GDP in excess of 50 percent (Armenia in 1992), and of growth of about

\footnotetext{
${ }^{4}$ In the extreme cases of both large economies, such as Russia, and small ones, such as Albania, it had happened that with an even larger private sector than in other countries (in terms of its contribution to GDP), as e.g., in Poland or Slovenia, the overall performance was much worse. Not the scope of liberalization or the range of the private sector were decisive in the changes of efficiency, but the institutional vacuum in the former countries and relatively sound arrangements and good policies in the latter.
} 
Table 4. Transition Countries: Duration of Recession and Growth in 1990-99 (In number of years)

\begin{tabular}{|c|c|c|c|c|c|c|}
\hline & $\begin{array}{l}\text { Transitional } \\
\text { Recession }\end{array}$ & Recovery & $\begin{array}{c}\text { Second } \\
\text { Generation } \\
\text { Contraction }\end{array}$ & Growth & $\begin{array}{c}\text { Total } \\
\text { Number of } \\
\text { Years of } \\
\text { Contraction }\end{array}$ & $\begin{array}{l}\text { Total } \\
\text { Number of } \\
\text { Years of } \\
\text { Growth }\end{array}$ \\
\hline $\begin{array}{l}\text { Albania } \\
\text { Armenia }\end{array}$ & $\begin{array}{l}3 \\
4\end{array}$ & 4 & 1 & $\begin{array}{l}2 \\
6\end{array}$ & $\begin{array}{l}4 \\
4\end{array}$ & $\begin{array}{l}6 \\
6\end{array}$ \\
\hline Azerbaijan & 6 & & & 4 & 6 & 4 \\
\hline Belarus & 6 & & & 4 & 6 & 4 \\
\hline Bulgaria & 4 & 2 & 2 & 2 & 6 & 4 \\
\hline Croatia & 4 & 5 & 1 & & 5 & 5 \\
\hline Czech Republic & 3 & 5 & 2 & & 5 & 5 \\
\hline Estonia & 5 & & & 5 & 5 & 5 \\
\hline FYR Macedonia & 6 & & & 4 & 6 & 4 \\
\hline Georgia & 5 & & & 5 & 5 & 5 \\
\hline Hungary & 4 & & & 6 & 4 & 6 \\
\hline Kazakhstan & 6 & 2 & 2 & & 8 & 2 \\
\hline Kyrgyzstan* & 5 & & & 4 & 5 & 5 \\
\hline Latvia* & 3 & 1 & 1 & 4 & 4 & 6 \\
\hline Lithuania & 5 & & & 5 & 5 & 5 \\
\hline Moldova & 7 & 1 & 2 & & 9 & 1 \\
\hline Poland & 2 & & & 8 & 2 & 8 \\
\hline Romania & 3 & 4 & 3 & & 6 & 4 \\
\hline Russia & 7 & 1 & 1 & 1 & 8 & 2 \\
\hline Slovakia & 4 & & & 6 & 4 & 6 \\
\hline Slovenia & 3 & & & 7 & 3 & 7 \\
\hline Tajikistan & 7 & & & 3 & 7 & 3 \\
\hline Turkmenistan* & 7 & & & 2 & 7 & 3 \\
\hline Ukrainc & 10 & & & & 10 & 0 \\
\hline Uzbekistan* & 5 & & & 4 & 5 & 5 \\
\hline
\end{tabular}

Source: Author's compilation based on data from Table 3 .

In countries labeled with * there was growth until 1990 and recession started only in 1991 . 
17 percent (Turkmenistan in 1999). It is possible to spot huge differences between the highest rates of contraction and growth for the same year. In the most extreme case this gap exceeded 55 percentage points, and that was in 1992. Even in the tenth year of transition, i.e., in 1999, the difference between contraction and growth was still larger than 20 percentage points. Altogether there are as many as 57 cases of the years with a two-digit rate of contraction, but not surprisingly only seven cases of the years with a two-digit rate of growth. To be sure, after the initial collapse of output, and as the transition process advanced, the lower were the fluctuations between these rates of growth.

The worst of all the years was 1992 . Then only Poland had modest (2.6 percent) rate of growth due to recovery that took off in the middle of that year. All other countries were suffering contraction in ranges from 2.9 percent in Kazakhstan and 3.1 percent in Hungary, to as much as a ruinous 44.8 percent in Georgia, and 52.6 percent in Azerbaijan. For the whole group of countries the recession that year was fairly deep and accounted for an aggregate 9.5 percent. This occurred when the transition process was moving peacefully, and only in certain minor regions were there local military conflicts. In the latter case the explanation of such dramatic contractions is obvious, since these conflicts contributed to further distortions, thus to the output dropping further still.

The best year so far was 1997, when the early fruits of structural reforms had already started to ripe. This was before the contagion of the East Asian financial crisis had set in and the fallout from Russia's financial crisis had a negative impact on the region's economic activity (Montes and Popov, 1999). In that year production fell in only five countries (including an unusual drop for this stage of transition of 26.1 percent in Turkmenistan), whereas output was growing in the remaining 20 countries. The highest rate of growth was recorded in Georgia and Estonia -- 11.0 percent and 10.6 percent, respectively. On average, the growth rate for the entire region weighted GDP was 2.0 percent. And then, in 1998, output fell again by 1.2 percent. It is possible and even likely that this was the last year when contraction was reported for the whole region of the EE and the FSU economies.

There is no clear pattern of a sequence of contraction, recovery and growth in the transition economies. The first decade of this endeavor must be seen as a distinctly atypical period, with no parallel to anything in the past, nor should it be expected to be repeated in the future. In this regard, several specific factors have been influencing the developments.

First, the moment output began to fall was different in individual countries. In a few countries, e.g., Latvia and Uzbekistan, it was feasible to postpone the beginning of the transitional contraction until the end of 1991 or the beginning of 1992 through postponement of liberalization. However, for the same reasons, that delayed introduction of structural reforms, production had already started to fall in 1989 in countries like Turkmenistan (within the FSU), Croatia (in the former Yugoslavia), or in Romania (in the former COMECON). Thus the initial impulse triggering contraction was not identical in each transition economy. In some countries, recession took hold because transition had just been initiated, whereas in others it happened because the transition process was not yet launched. 
Second, the deepness of recession was different in every country owing to the initial distortions associated with centrally planned economies, on the one hand, and to the applied adjustment policies, on the other. The more severe the distortions--e.g., the burden of nonperforming foreign debt, the rate of open inflation and shortages, the range of price subsides, the array of inefficient state companies, etc.- the deeper was the following contraction. But, during the early years, the levels of contraction were also larger in countries that tried to exercise a too radical liberalization policy. If both these occurrences had taken place simultaneously - and that was precisely the case in Poland in 1989-90, and Russia in 1992-93-the early contraction was relatively deeper. ${ }^{5}$

The reverse example, that is the case without distortions typical for reformed statist economy and with gradual shift towards liberalization, does not exist. However the Chinese and Vietnamese experiences of the 1990s show that, if there is not too much of the first characteristic and not too little of the second, growth can be fast and sustained, at least for a period of time. ${ }^{6}$

Third, the duration of transitional contraction was shorter in these countries, since they had already initiated reforms of their economies under the previous central planning system. The more the economic and financial mechanism of the centrally planned economy was reformed, the shorter was the introduction of the critical mass of new market-oriented arrangements. Consequently, it took less time to improve allocative efficiency and hence to return to the path of growth in this group of countries. The cases of Hungary and Poland as well as Slovenia fell into this category. This claim is also supported by the experience of Estonia, where certain market-oriented reforms were also executed relatively earlier, compared with other FSU republics.

This observation is not contradictory with the conclusion that those limited reforms also contributed to growing financial destabilization (Kornai, 1986). The mixed outcome was also causing a mixed impact, first on contraction and then on expansion. Again, the best examples are Hungary, and particularly Poland. In this country, the inconclusive reforms of the 1980 s led to fiscal and monetary instability. Nevertheless, these changes have proven to be of much greater importance in the longer run and have contributed to greater flexibility and a better ability to adjust. Thus the impact of these contradictory tendencies turned out to be positive for future growth: recovery came sooner and growth was faster.

\footnotetext{
${ }^{5}$ Of course, the Russian case is quite different from the Polish case. In Russia, GDP fell by 8.8 percent already before substantial liberalization took place, i.e., in 1990-91. In Poland, there was growth until mid-1989, when the pace of liberalization was fundamentally accelerated, and only since then has output started to fall.

${ }^{6}$ The opposite tendencies vis-à-vis recession and growth in China and Russia should be seen as the most striking event in the world economy in the last decade of $20^{\text {th }}$ century. Whereas during this time GDP in China was doubled, in Russia it was halved. This also has significant geopolitical implications.
} 
Fourth, even when recovery follows a period of contraction, it does not mean the transitional depression is over. During the decade of the 1990 s there were at least ten cases of returning contraction after the economy had already bottomed out. So far, six cases of such "second generation transitional contraction" have lasted for more than just a year. These events are not caused solely by external shocks, but are also due to the lack of both sound fundamentals and strong institutions that are supposed to uphold growth when it eventually comes. In another words, in transition economies, even more than in the mature markets, growth is not guaranteed because it has already taken place. It must be maintained by good policies, which may not be enough, if good institutions are not in place or do not support good policies. Undoubtedly for this simple reason it must be expected that the future will bring instances of falling output. Some of them will result from failure of the policies, and some from the business cycle mechanism. However, as far as the cases of "second generation transitional contraction" are concerned, they have mostly resulted from wrong policies or negative external shocks, or the incidence of both. The business cycle mechanism in post-socialist countries has not yet been fully set in motion, since it is a function of the strength of the market mechanism, which is just being introduced.

Fifth, it must be remembered that if national income was lost in the past due to policy failures, its current and future growth are not compensation for this loss. Only in instances when the later growth is coming about because the previous fall in output was caused by structural reforms, than such contraction can be seen as a specific "institutional investment." If not, recession and depression simply mean an unrecoverable lose of welfare (Nuti, 1992).

The first decade of the transition came to an end with aggregate GDP for the whole region measuring barely about 70 percent of the pre-transition level. With this performance in mind comparisons are always made of current output of particular countries in relation to their output levels at the onset of transition and, compared with countries' relative production of other centrally planned and market economies (see Table 3). However, it may be revealing to look at the aggregate output levels over the whole decade of $1990 \mathrm{~s}$. If a certain country has recovered to the pre-transition level of output and another country has not, the usual interpretation suggests that the former country is doing better than the latter, at least as far as the growth process is concerned. But it may happen that in relative terms output in the latter country was higher over the entire period of the 1990s than in the former country.

Consider the hypothetical sequence of four years of recession, followed by recovery and growth in two countries, A and B. In country A output fell by 10 percent during the second year of recession sequence, and during the third year output returned to the pretransitional level. In the fourth year country A's economy was still growing, but only by 2 percent, which was sufficient to pass the pre-transitional level by this amount. Thus, the sum of output over a period of four years is equal to 392 units $(100+90+100+102)$. In country B output contracted only by 1 percent in the first two years and by 1 percent in the third year, and again by 1 percent in the fourth year. So, at the end of the four-years recession period, country B's output stood at 97.03 percent of the level of the starting year. The sum of output over the four-years period is $394.03(100+99+98.01+97.02)$. This means that, despite country B's current position, i.e., at the end of the whole sequence of contraction-recoverygrowth, Country A's production (one year flow) is larger (i.e., 102 units), although total 
aggregate production for the whole time span is larger in country B, where the current level of production (again one year flow) stands at about 97 units. In the latter case, where current output is smaller by five units (102 minus 97), the sum of the total four years' output is larger by two units (394 minus 392).

The cases of Slovakia and Uzbekistan have followed the above recession-growthrecovery' pattern. The index of 1999 GDP, if compared with that of 1989 , is equal to 101.5 percent and 92.3 percent, respectively. However, for the former the GDP combined for the whole decade, i.e., 1990-99, is equal to 883 percent of the 1989 GDP, whereas for the latter it amounts to 901 percent of the output from that year. The illustration of the relevant sums of GDP combined over the entire decade 1990-99 for 25 transition countries is shown in Figure 1.

The message is mixed again. In certain instances, while the relative aggregate GDP for the entire decade is larger, simultaneously the current relative level of GDP is smaller. So, which country is better of? Is it the country with the higher current level of GDP compared with the pre-transition output, though the sum of GDP for the entire transition period is relatively lower than in an alternative case? Or is it the country where the GDP amassed over the whole transition decade is relatively larger than otherwise, although current production is still relatively lower when compared with the altemative case? It depends. The issue is that from the formal point of view (leaving aside important structural changes), the same category of GDP is concerned. Though from another viewpoint a somehow already changed society is taken into account. Once again today's higher income is not always compensation for yesterday's loss. This is so, because some people lost and others gained. This outcome is bound to cause social stress and political tensions, making implementation of economic policy and structural reforms still more difficult. Thus, what is important in this regard is the fluctuation of the rates of contraction and growth. It seems that it is more favorable for long-term fast growth and nations' welfare if the changes are less hectic and less volatile and the fluctuation of these rates is reduced and thus there is a smoother process of quantitative changes vis-à-vis output.

Over the last decade, the whole group of 25 post-socialist transition economies produced barely 7.6-fold of what they had produced in 1989. The corresponding aggregate index for the FSU stands at 673 percent and for the EE at 895 percent. This means that in Eastern Europe it has taken 11 years to produce a GDP that matches the 1989 GDP times 10. From the statistical standpoint, it is the same as if there were no recession, but simply a stagnation lasting 11 years-from 1990 until 2000.

\section{Policy Response AND THE Role of Institution-BUILding}

At the current stage of transition the post-socialist countries have much more in common with other emerging markets than was the case just a few years ago. Then it was too often believed that these countries were supposed to tackle similar structural problems as other regions with distorted economies. This was not true then nor is it now, despite the growing similarities between the challenges all these countries are facing. Considering the 
Figure 1. Transition Countries Index of Aggregated GDP for the Decade, 1990-99 (1989=100)

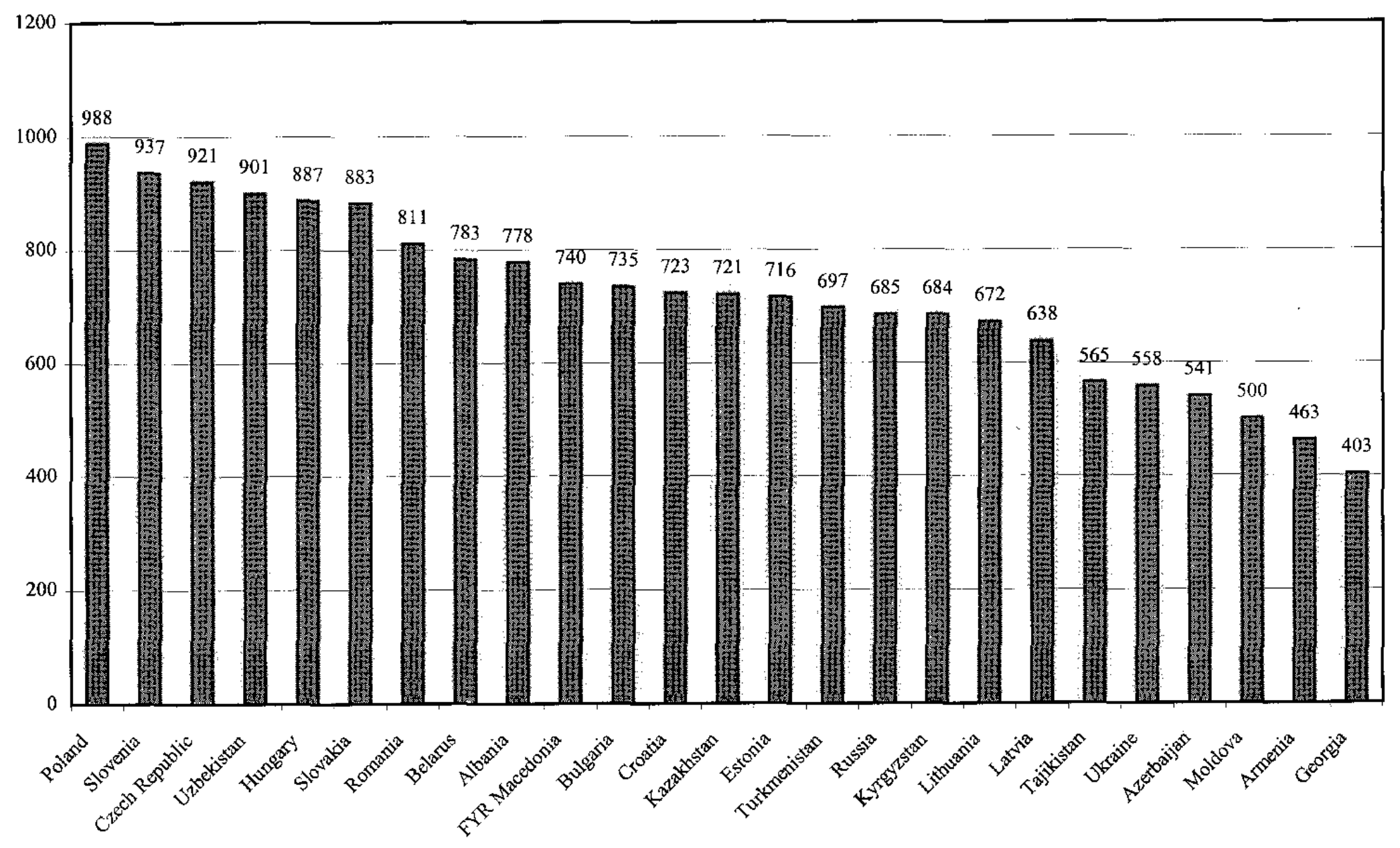


policy options from the standpoint of future growth, the specific features of post-socialist economies must still be taken into account very seriously. Of crucial importance is the process of institution-building.

From an economic perspective the statist centrally-planned system collapsed because of a lack of ability to adjust in the face of the rapidly changing environment of the world economy. Thus the rigid, inflexible system of central planning, which was enmeshed in numerous distortions, proved to be unable to improve its competitiveness. While globalization represented a threat for countries unable to adjust, it was the impetus to overhaul the inefficient centrally planned economic system. In addition to the growing internationalization of economic links and vast political changes, technological progress served as a critical catalyst in deciding that the time for comprehensive transition had arrived. Otherwise it would have been difficult, if possible at all, for 25 countries in transition to adjust to growing development challenges and take advantage of the prospects for long-term expansion. Two issues have emerged in this connection.

First, the initial policies must tackle the new challenges within the framework of inherited old institutions. The institutions, i.e., the rules and the organizations that help to enforce the rules, always matter, and during transition they matter even more (North, 1997). But, within the broader concept of the meaning of institutions, the market culture and the behavioral aspects of the market economy must also be seen. Hence, even if the laws regulating the rules of an emerging market economy have already been adopted by the transition countries, and even if the organizations charged with enforcing observance of the laws have been established there still remains the challenge of relatively lagging behind the market culture and behavior.

Second, as time is passing, these very institutions must also change for the purpose of implementation policies. This means that while the long-run quality of institutions (and their short-term ability to support the course of actions) is a matter of policy too, in the short-run the institutions are given. Hence, the policies carried out must be performed within the limits imposed by the existing institutional arrangements. In other words, there were, and to a degree still are, policies that cannot be implemented in the transition economies because of institutional weakness. This shortcoming, which is so obvious at the end of the first decade of post-socialist transition, was not generally understood at the onset. Quite the contrary.

Not surprisingly, weak institutions - those tailored to the needs of the outgoing statist system which were marked by dominance of the government sector and the vast bureaucratic control, or later only emerging from naught-were weakening the efficiency of policy directives. Considering such institutional weakness there were various reactions that should be expected, yet often they were not anticipated, precisely because of the negligence of institutional arrangements. Most important in this respect was the lack of an early positive supply response. Many policymakers and their advisors (including international organizations) expected that output should start to grow soon after liberalization took place but only if a certain critical mass of privatizations of official entities were executed. 
Conversely, despite fast and far-reaching privatization for a prolonged period of time there was no improvement in allocative efficiency; in some instances it even deteriorated. It would not be correct to assume that the deterioration occurred because private assets were less productive than those owned by the government, though there were incidences of privatization being followed by contraction. If the transitional recession and depression are being associated with ongoing privatization efforts, this would be a mistake, since these events must be linked to the institutional bottleneck. For the emerging private sector to prove its superiority at least a rudimentary streamlining of institutional arrangements has to be in place.

Another important observation is that within the same or similar institutional arrangements alternative sorts of policies may be implemented. This means that, regardless of the existing institutional arrangements at a given moment of time, the policies can be better or worse. The policy response can be more suitable to tackle the issues in one country, and less suitable in another. Therefore though the institutions do not differ, the different policy responses deliver different results.

It is also possible that even within the framework of weaker institutions the outcomes are better than they might be in other places enjoying stronger institutions. And this is exactly the result of better policies. Thus institutions do matter, but so do policies. It may happen that economic performance is healthier in a country with better or worse institutions, or in a country with better of worse policies. To some extent these are complementary matters, to some extent they may substitute for each other. As far as economic growth is concerned this explains why some countries, ceteris paribus, are doing better than others. It also explains why in some of them economic performance is more remarkable over one period and worse during another, despite the fact that in the meantime the institutional arrangements have been upgraded and improved.

A fine example of the inter-relation between policies and institutions is the Polish economy. In this country, due to gradual yet committed institution-building and because of sound financial policies, following the recovery that started in mid-1992 growth accelerated rapidly after 1993. However, after 1997, the pace of growth has slowed down significantly (and much more than expected). This deceleration occurred despite the ongoing advancement of institution-building over all those years. To a modest extent it was provoked by external shocks, but mainly it was caused by a deterioration of economic policy measures. The analyses on external shocks fall short of explaining the drop of the rate of GDP growth from as much as 6.7 percent in 1995-97 to about 4.5 percent in the subsequent three years, i.e., 1998-2000. The quality of policy programs does explain the deterioration.

Of course, the best combination is to have sound policies and good institutions. And, no doubt, the worst is the opposite, i.e., weak institutions and bad policies. From this perspective, unfortunately in transition economies the latter combination happened more often than the former. Not surprisingly the transitional recession turned into the Great Transitional Depression. 
At the early stages of transition there is no obvious rule with the respect to the combination of quality of institutions and policies. Later, presumably, these forces start to interact and invigorate with each other. Before this occurs it may happen that the relatively better institutions can dampen the policymakers' commitment to further structural reforms and continued institution-building, since these are never easy. They are continuing processes, not just an episode.

Or, it may go the other way around, with distortions, difficulties, tensions, crises, etc., pushing governments to reform the institutional order still further. Yet the economic implications of these questions have great political importance. The answer depends on the vision and ability of the political elite to formulate long-term development plans and to be strongly involved in the feedback of the ongoing process of political liberalization, i.e., democratization.

Hence, the issues are quite complex. It is excellent when progress with institutionbuilding evolves naturally from the wisdom of the people and the determination of their leaders. It happens. But experience shows, too, that quite often institution-building gets momentum only if the problems are increasing, so "the worse, the better." It is then that strong pressure appears especially from the business sector, and also from the outside and pushes for early structural reforms. International organizations also contribute to the process by providing technical advice and financial assistance on conditional terms that are contingent on successful implementation of proper policies and reforms.

\section{External Shocks and the Catching-up Process}

There is a widespread conviction that a push towards market economy in postsocialist countries must bring about better allocative efficiency and increased competitiveness and this is the strong argument behind the rationale to do so. Thus, in due time it must bring about a growing output and a better standard of living. Yet to accomplish this goal not only does the pre-transition level of output need to recover, but they must return to a path of quick and sustained growth. Only then will there be a chance to catch-up, by means of a gradual and lasting process of lessening the development gap between transition economies and wealthier industrial countries.

While looking into the future, there is always the temptation to presume that things will be fine. Such optimism may seem reasonable from the policymakers' perspective, especially since they always believe they know what ought to be done and that it is the unfavorable external shocks that make their ambitious plans impossible. Unfortunately, quite often these assumptions do not hold true. Consequently, the future seldom looks as bright as envisaged couple of years earlier. Despite such experiences, too optimistic expectations tend to be repeated time and again. Post-socialist economies and their leaders are not any exception to this rule. It may be added that international organizations are following this pattern of behavior too (World Bank, 1997). Moreover, at least at the outset of transition these agencies have made a strong impact on such excessive optimism in transition countries. 
There is nothing wrong with optimistic expectations, if they are based on knowledge and a sound commitment to structural policies, and draw the right conclusions from historical experience. Otherwise too much optimism becomes too much ignorance, which always acts against growth and its sustainability. Therefore the considerations about catching-up in transition economies should draw from these countries' own experiences as well as from the characteristics of growth processes occurring elsewhere.

As for experience it must be clearly understood why some countries--actually very few-have been able to produce in 1999-2000 more than they did in 1989-90, while many others are still not able to do so. In other words, there is a question to what extent the rate of growth in the future will differ between particular emerging markets in the EE and in the FSU region. Can growth differ as significantly as it has over the last decade? This is hardly imaginable, because there were some unique reasons for the divergent growth patterns, which are unlikely to reappear.

First, there were local military conflicts. Countries affected by these misfortunes obviously lost a significant part of their production. Especially Armenia, Azerbaijan, Georgia, Moldova and Tajikistan in the FSU region, and several Balkan countries in the EE region, were severely harmed by heavy infrastructure and financial loses owing to military operations. It is a disaster to lose in one year as much as 21.1 percent of GDP in Croatia in 1991, 52.6 percent in Armenia in 1992, 18.9 percent in Tajikistan in 1994, and 37.3 percent in Yugoslavia in 1999. In some places the situation remains unstable and unpredictable. As for the future, all further predictions presume that there will be no more such conflicts, yet this is not guaranteed. If, however, the transition process during the next decades evolves peacefully - and all necessary attempts to secure this course must be undertaken - it is reasonable to expect accelerated growth. In the 1990s output started to grow rapidly in certain countries immediately after the military conflicts ceased. But if regional conflicts continue, then sluggish economic performance and depression will last for several more years.

Second, they were external shocks, which were causing additional difficulties. Among them, the shock following collapse of the former Soviet Union was extraordinary. For this reason the transitional recession was much deeper in FSU economies than in EE countries. The breakup of the former Yugoslavia was a great shock, too. Meaningful, though with milder implications, was dissolution of the COMECON, i.e., the trade bloc of socialist countries. More recently, the contagion effects following the 1998-99 Russian financial crisis have shown how vulnerable the FSU republics are to crises occurring in countries with which they have strong links. Nonetheless, owing to the diversification of trade partners and the directions of capital inflows, there is a likelihood that this vulnerability will decline. Yet the risk of external shocks will remain, which can diminish growth prospects. Hence a shield against negative external shocks ought to be created. ${ }^{7}$

${ }^{7}$ During the implementation of structural reforms and a development program "Strategy for Poland" (1994-97) there was a special task force led by the Deputy Premier and Minister of Finance, that worked on early warning and policy responses to counteract the threat of 
Third, certain events are good news and bad news at the same time. There are the economies, mainly among the FSU countries, that rely to a large extent on specific commodity prices. For example, natural gas and oil for Turkmenistan, oil for Azerbaijan and Russia, cotton and gold for Uzbekistan, crude ore for Ukraine, etc., are highly significant for these countries' income. Without taking a closer look at the fluctuation of these prices, it is not possible to explain the shifts in the rate of growth in Turkmenistan, moving from minus 26.1 percent to plus 17 percent between 1998 and 2000, or in Azerbaijan moving from minus 11.8 percent to plus 5.8 percent between 1995 and 1997. When the prices of oil and gas were plummeting to their lowest levels since 25 years, this was a negative shock for the countries that depend on the export revenues of these products. But at the same time, the lower prices of oil and gas were positive shocks for importers, including a majority of the EE economies. Thus, through the influence of lower prices on their terms of trade the price fluctuations affected rate of growth in these countries in a positive way.

Fourth, in post-socialist countries not only the market economy is emerging, but so is democracy. It is a value by itself, yet at the same time inter-linked in a complex manner with the process of economic growth. There is no apparent relation between the emerging markets and democracy (Alesina, 1997), and marketization, i.e., the process of transition to democracy from a statist system of government. There are the examples of economies with fast and sustainable growth without much democracy, as well as countries with long-lasting depression under authoritarian regimes. There are plenty of cases of fast growth under democracy as well as opposite example of democracy with sluggish growth. However, even if the process of democratization is bumpy in certain transition countries and has not improved economic growth immediately, it will do so in the longer run. Under this perspective, democracy assists growth, because it corrects policy excesses. Of course, democracy works better if the market performs well — and the other way around.

Fifth, in certain cases an extraordinary fall in output was also due to a lack of wise macroeconomic policies. The best examples here are the failure of fraudulent financial pyramid schemes in Albania and the Russian financial crisis, but there were many ill-advised policies and wrong decisions in other economies too. As for the future, as a consequence of increasing maturity of both market and democratic institutions, it seems reasonable to expect more responsible policies. So further institutional advancement will contribute to a relatively higher rate of growth.

Whereas all of the above five arguments are based on lessons from the past, there are certain others pointing to concurrent processes going on in the global economy, which can be promising for the prospects of fast and sustained growth (Fischer, Sahay, Vegh, 1997). Against this background, it is rational to expect that the process of catching-up with more developed countries will indeed take place.

negative external shocks, especially vis-à-vis risks stemming from the liberalization of financial markets. This tiny team worked in very discreet manner, out of the media spotlight, what was crucial for its success. 
Here in turn, the first argument is that the course of catching-up with technological progress is to broaden its momentum on a global scale. The transfer of new technologies from advanced economies to catching-up countries contributes significantly to the growing competitiveness of all emerging markets. If macroeconomic fundamentals are sound and financial stabilization is accomplished, and if the political institutions perform well, then technology transfer brings about a major acceleration of the rate of growth. On this precise field the catching-up process is going to be most visible and most fruitful. It makes sense to presume that, ceteris paribus, in the long term transitional economies will gain at least one additional percentage point of growth due solely to this factor. Technology transfer is raising the level of labor skills faster than its costs, i.e., labor productivity is growing faster than wages. For this reason production located in less developed countries by developed countries will grow faster than the global average. This is also true for the transition economies.

This mechanism for catching-up has already been set in motion, although it is difficult to spot it in the complexity of changes influencing the contraction-recovery-growth cycle. If the catching-up process does not take hold in the current phase of the global technological revolution and transfer of know-how, the transitional recession could be even deeper, last longer, and the recovery would be weaker, and growth slower. The spillover effects, i.e., spreading out of new technologies and know-how, upgrades the skills of labor. Unfortunately, the simultaneous and harmful brain drain process threatens to diminish the ability of developing and transition countries to compete and expand in global markets. Such threat must be counteracted by better compensation for and larger investment in the human capital. For instance, the inward FDI works against the flight of human capital. In countries absorbing most of the FDI flowing to post-socialist economies, e.g., Hungary and Poland, there is already a net inflow of skilled labor, which means that more qualified people are coming into these countries than are leaving them. This is good for future growth.

The second argument relates to the process of integration into the global economy. Transition is an indispensable part of globalization, and post-socialist economies have a chance to become one of the major beneficiaries of this multi-track process. However, the picture is mixed here and this time the geopolitical position matters more. In the best situation are the EE countries that are negotiating access to the European Union: first is the Czech Republic, followed by Estonia, Hungary, Poland and Slovenia, and later Bulgaria, Latvia, Lithuania, Slovakia and Romania, and soon Croatia. Integration into the EU will give these countries strong boost in growth. Rapid upgrading of institutional arrangements by these countries along the lines of the rules observed in the EU, will facilitate long-term growth. These countries can also count on relatively larger inflows of FDI. Indeed, expectations for their future membership in the EU have already attracted considerable inward FDI. ${ }^{8}$ Net transfer of resources from Western to Eastern Europe has worked as a

${ }^{8}$ Out of about $\$ 104$ billion of inward FDI over the period $1989-99$, about 55 percent was allocated to a group of five EE countries that were most advanced in both the transition and their accession negotiations with the EU, i.e., the Czech Republic, Estonia, Hungary, Poland and Slovenia. The largest of them, Poland, absorbed about 20 percent of this amount. As for 
catalyst of growth and thus the process of integration with the EU should accelerate the longterm rate of growth, perhaps by another percentage point or so.

The third argument is linked to progress in the accumulation of knowledge and reasoning on economic and financial matters. Not yet appreciated in a similar way as the technological revolution, progress increasing in intellectual capacity and know-how also contributes to catching-up, since macro and microeconomic management are a more complex challenge than they used to be (Kozminski, 1993). Experience suggests that there is a certain lag vis-à-vis acquiring such knowledge for both cultural and political reasons, yet learning by doing is already well on the way. Although impossible to measure, this factor enhances the pace of growth too.

And the fourth argument is that the advancement of institution-building contributes to getting rid of systemic bottlenecks and structural distortions inherited from the past as well as created at the early stages of transition. This, in turn, boosts labor productivity and overall economic efficiency.

So there are grounds to assume that the transition economies will grow faster than the global economy and the developed industrial countries, and in due time they may catch up with the latter group. Yet fulfillment of the catching-up theory needs support. Various political, cultural and institutional factors must come into existence and specific conditions must be fully met to set the mechanism of catching-up in motion. After the first decade of transition, in several countries, though not yet in all of them, these factors and conditions seem to have taken root at least to a certain extent. Against this background, it seems possible to outline alternative scenarios for catching-up and the policy recommendations to facilitate implementation of the optimistic scenarios.

\section{FOUR SCENARIOS FOR LONG-TERM GROWTH UNTIL 2050}

Transition can be seen as a specific endeavor that shifts part of the global economy from one model of development to another. Before the recent recession, though the early expansion followed the pattern of growth cycles distinctive to the centrally planned system, all these economies were growing. Until they lost momentum in the late 1980 s, they were catching-up with more developed regions. Now, assuming that the Great Transitional Depression has come to the end, there will be growth along the business cycle patterns distinctive to the market system. Further, there is an implicit assumption that long-term

total FDI placed in the EE region, these five countries received about 77 percent of foreign direct capital, while Poland alone received almost 30 percent. It is important to emphasize that in these cases the capital flow is actually a net inflow, because outward FDI virtually does not exist in these countries. That is, of course, if the capital flight from Russia is disregarded. If it is not, then the net flow of capital to the whole EE and FSU region over the first decade of transition is negative. It implies that more capital has left the region than was invested there--with all the harmful implications for recovery and growth. 
growth will evolve around a trend derived from business cycle fluctuations. Hence the postsocialist economies are going through a process of changing the substance of their cyclical growth. They do not move from a system where there was no growth (since there was growth and not too slow) to a system where growth will resume per se and will automatically be of a "better character." That must still happen.

There are various forecasts for the coming years but no forecasts for a further decline of output in any of the transition economies. There is just a couple of cases where a drop in output is expected and only for a single year. This presumes that developments will go peacefully and severe external shocks will be avoided. Yet misfortunes cannot be ruled out a priori. In 2003-04 the GDP index will look less depressing than now, although not as impressive as one would like to see it. In 2004 only in 7 or 8 out of 27 countries the output will surpass GDP of 1989. At the other end of the list, output in another eight countries will remain below two-thirds of the 1989 standard. This will be altogether after 15 years of transition (Table 5).

Sometimes, owing to market exchange rate instability, a change of the relative value of the national currency may suggest a fall in GDP measured in U.S. dollars, whereas GDP is actually growing. ${ }^{9}$ For this reason it is justified to take a closer look at the evaluation of GDP per capita on the basis of purchasing power parity. This indicator ought to be regarded as a point of departure to the catching-up process (Table 6).

There is an interesting phenomenon here. Unlike the EU and other advanced market economies, in the transition economies there is a large gap between the GDP measured in current prices, i.e., the market exchange rate, and its valuation on the basis of purchasing power parity (PPP). The progress of opening up in the transition countries and integration into the world economy is diminishing this gap, but it still remains. For this reason, there is going to be a lengthy process of real appreciation of the currencies of transition economies. ${ }^{10}$ Indeed, it is already well under way. If from time to time the currencies of the transition economies do depreciate - and indeed sometimes devaluation is a spectacular event - it is not contrary to the long-term upward trend.

\footnotetext{
${ }^{9}$ For instance, it occurred in Poland in 1999, when GDP estimated in current dollars dropped by 2.1 percent, whereas in the real terms, when measured in terms of constant domestic currency, increased by 4.1 percent.

${ }^{10}$ The issue of depreciation and appreciation will disappear from the policy agenda when certain countries join the EU and abandon their national currencies. It will be the easiest exercise in countries presently under a currency board regime, e.g., Estonia. In such case it will be done by converting from the D-mark (the denomination used under the currency board arrangements as anchor) to the euro. In the longer run, all new EU members from Eastern Europe will join the euro zone.
} 
Table 5. Transition Countries: Real GDP Index-Forecast for 2003-04

$(1989=100$ and $1999=100)$

(In percent)

\begin{tabular}{|c|c|c|c|c|c|c|c|c|}
\hline & \multicolumn{2}{|c|}{ Index 1999} & \multicolumn{4}{|c|}{ Rate of Growth } & \multicolumn{2}{|c|}{ Index 2003(4)* } \\
\hline & $1989=100$ & $2000^{-}$ & 2001 & 2002 & 2003 & 2004 & $1999=100$ & $1989=100$ \\
\hline & \multicolumn{8}{|c|}{ (In percent } \\
\hline Poland & 121.6 & 4.8 & 5.1 & 5.5 & 5.8 & 4.9 & 129.0 & 156.8 \\
\hline Slovakia & 101.5 & 3.8 & 4.6 & 6.4 & 6.0 & 6.9 & 130.9 & 132.9 \\
\hline Slovenia & 107.6 & 4.0 & 3.9 & 4.2 & 4.1 & 4.8 & 122.8 & 132.2 \\
\hline Albania & 92.5 & 7.0 & 6.7 & 8.3 & 6.9 & 6.5 & 140.8 & 130.2 \\
\hline Hungary & 99.2 & 5.3 & 5.2 & 5.4 & 5.1 & 5.5 & 129.5 & 128.4 \\
\hline Czech Republic & 94.7 & 2.6 & 3.6 & 4.8 & 4.7 & 4.4 & 121.8 & 115.3 \\
\hline Uzbekistan & 92.3 & 3.8 & -1.0 & 2.2 & 3.8 & & 109.0 & 100.6 \\
\hline Croatia & 77.2 & 2.6 & 3.5 & 4.4 & 4.8 & 4.7 & 121.6 & 93.9 \\
\hline Romania & 73 & 5.3 & 5.4 & 5.3 & 5.0 & 4.6 & 128.4 & 93.7 \\
\hline Estonia & 75.7 & 5.5 & 5.5 & 5.1 & 4.5 & & 122.2 & 92.5 \\
\hline FYR Macedonia & 72.0 & 4.8 & 5.5 & 5.0 & 4.5 & 3.6 & 125.7 & 90.5 \\
\hline Bulgaria & 66.8 & 4.1 & 5.0 & 5.2 & 4.7 & 4.4 & 125.7 & 84.0 \\
\hline Lithuania & 65.4 & 5.3 & 5.3 & 5.7 & 5.2 & & 123.3 & 80.6 \\
\hline Belarus & 78.2 & -8.1 & 1.7 & 3.1 & 5.7 & & 101.9 & 79.6 \\
\hline Latvia & 60.1 & 4.9 & 4.8 & 5.5 & 5.3 & & 122.1 & 73.4 \\
\hline Kazakhstan & 60.2 & 3.3 & 4.5 & 5.9 & 6.1 & & 121.3 & 73.0 \\
\hline Kyrgyzstan & 60.4 & 4.5 & 4.1 & 4.2 & 4.4 & & 118.3 & 71.5 \\
\hline Azerbaijan & 45.2 & 7.3 & 9.1 & 9.7 & 9.0 & & 140.0 & 63.3 \\
\hline Turkmenistan & 51.2 & 5.3 & 5.1 & 5.0 & 6.1 & & 123.3 & 63.1 \\
\hline Russia & 56.1 & 2.2 & 2.7 & 2.0 & 3.4 & & 110.7 & 62.1 \\
\hline Armenia & 42.5 & 6.2 & 6.9 & 7.1 & 7.2 & & 130.3 & 55.4 \\
\hline Tajikistan & 44.1 & 5.0 & 5.1 & 5.0 & 5.9 & & 122.7 & 54.1 \\
\hline Georgia & 33.8 & 8.0 & 7.8 & 7.8 & 7.5 & & 134.9 & 45.6 \\
\hline Ukraine & 35.7 & 0.2 & 3.3 & 3.9 & 4.6 & & 112.5 & 40.2 \\
\hline Moldova & 30.5 & 3.7 & 4.7 & 5.6 & 6.1 & & 121.6 & 37.1 \\
\hline Bosnia-Herzegovina & na & 6.1 & 4.6 & 3.8 & 3.1 & 3.7 & 123.2 & $\mathrm{Na}$ \\
\hline Yugoslavia & na & 15.4 & 13.2 & 10.9 & 8.1 & 5.9 & 165.8 & $\mathrm{Na}$ \\
\hline
\end{tabular}

Sources: Index 1999 from Table 3. Forecast for 2000-04 from PlanEcon 1999a and 1999b. $\mathrm{Na}-$ data not available.

* 2003 for the FSU, and 2004 for the EE countries. 
Table 6. Transition Countries: GDP Per Capita in 1999 and 2003-04, PPP Basis

\begin{tabular}{|c|c|c|c|c|}
\hline & 1999 & $2003(4)$ & Growth (in PPP\$) & Growth \\
\hline & \multicolumn{2}{|c|}{ (In US\$) } & \multicolumn{2}{|c|}{ (In percent) } \\
\hline Slovenia & 14,267 & 17,344 & 3,077 & 21.6 \\
\hline Estonia & 9,096 & 16,048 & 6,952 & 76.4 \\
\hline Czech Republic & 9,472 & 11,442 & 1,970 & 20.8 \\
\hline Slovakia & 8,395 & 10,954 & 2,559 & 30.5 \\
\hline Hungary & 8,063 & 10,648 & 2,585 & 32.1 \\
\hline Croatia & 8,284 & 9,528 & 1,244 & 15.0 \\
\hline Poland & 7,232 & 9,255 & 2,023 & 28.0 \\
\hline Latvia & 6,341 & 7,877 & 1,536 & 24.2 \\
\hline Belarus & 5,722 & 5,737 & 15 & 0.3 \\
\hline Russia & 4,539 & 5,087 & 548 & 12.1 \\
\hline Bulgaria & 3,758 & 4,796 & 1,038 & 27.6 \\
\hline Lithuania & 3,680 & 4,520 & 840 & 22.8 \\
\hline Romania & 2,962 & 3,837 & 875 & 29.5 \\
\hline Armenia & 2,842 & 3,662 & 820 & 28.9 \\
\hline FYR Macedonia & 2,897 & 3,423 & 526 & 18.2 \\
\hline Turkmenistan & 2,891 & 3,376 & 485 & 16.8 \\
\hline Kazakhstan & 2,482 & 3,028 & 546 & 22.0 \\
\hline Yugoslavia & 1,828 & 3,027 & 1,199 & 65.6 \\
\hline Uzbekistan & 2,612 & 2,721 & 109 & 4.2 \\
\hline Azerbaijan & 1,970 & 2,689 & 719 & 36.5 \\
\hline Ukraine & 2,348 & 2,641 & 293 & 12.5 \\
\hline Georgia & 1,950 & 2,570 & 620 & 31.8 \\
\hline Kyrgyzstan & 2,211 & 2,472 & 261 & 11.8 \\
\hline Moldova & 1,745 & 2,104 & 359 & 20.6 \\
\hline Albania & 1,474 & 2,025 & 551 & 37.4 \\
\hline Tajikistan & 748 & 848 & 100 & 13.4 \\
\hline
\end{tabular}

Source: PlanEcon 1999a and 1999b.

* 2003 for the FSU, and 2004 for the EE countries. 
These data better reflect the actual level of development and the living standard. Thus it is also a better measure (and not the GDP per capita at the current market exchange rate) indicating where indeed these economies and societies are at the time. For instance, in Russia the GDP per capita-in 2000 at around $\$ 1,500$ in terms of the market exchange ratestands at only 13 percent of the Slovenian GDP. Even with all the drawbacks of the recession, Russia is not that far behind. In the future, following progress with financial stabilization, this gap will decrease along the lines of a real ruble appreciation and, most likely, Russia will also achieve a faster rate of growth than in the more advanced postsocialist countries.

So where will all these post-socialist countries be in a generation or two? From the perspective of their long-term growth capacity, and thus the capacity to catch up with advanced industrial countries, four distinct post-socialist economies groups can be specified.

The first group can be called "the gainers" and will consist of economies able to sustain a rate of GDP growth at least two times higher than in advanced market economies over the very long-term. As a benchmark the recent rate of growth in the EU can be used. Though future growth is not a sure figure in this case either, it seems reasonable to assume that, by and large, it will sustain around the level achieved in 1997-2000, i.e., 2.5 percent. This implies that over the coming decades the annual rate of growth for the gainers will be about 5 percent, oscillating mostly between 4 and 6 percent.

The second group, "the even-runners", will be able to maintain a pace of growth similar or slightly higher than the EU, so growth will oscillate around 3 percent on average, moving between 2 and 4 percent. As a result, these countries will not be catching-up with the more advanced part of the European economy, or if they do it will happen very slowly. Consequently, the relative distance between these two groups will change only very modestly, yet given the different bases, the absolute distance will rise still further. Also the development gap between this group and the gainers will increase.

The third group, let us call them "the laggards" due to a lack of ability to make transition work to their own advantage, will grow even less than the EU economies (and the even-runners). Their long-term growth will not exceed 2 percent or may even stay below this low level. Thus in the future their relative income, compared with other groups of transition economies, will lag even further behind than at the turn of the millennium. There are many arguments that all post-socialist countries will be growing economies, yet it would be unwise to assume that, owing to the coincidence of unfavorable circumstances and policies, the worst among them will not be driven from time to time into another recession. Accordingly, their long-term growth could be very meager.

And there is a fourth group, or at least there is a chance that it will appear- "the frontrunners." These countries, under a lucky coincidence of favorable circumstances and good policies, will enjoy an average rate of growth approximately three times higher than the EU, i.e., 7.5 percent. While running between 6 and 9 percent annually, they will approach the EU production standard, and at the same time, they will distance themselves from all other post-socialist economies. 
These are some general reflections vis-à-vis alternative pace of growth in the transition economies. It does not mean, of course, that each country that grows faster will enjoy higher output and, consequently, a better standard of living than a country growing at a lower rate, although in the longer run this will eventually happen. However, for several years the reverse situation may occur, because of the logic of the catching-up mechanism. This means that countries moving from a lower level of output in 2000, like Azerbaijan in the FSU region, or Albania in the EE region, may report faster growth than, say, Estonia and Slovenia, for a number of years will still have relatively lower income.

In Azerbaijan the GDP per capita on a PPP basis was estimated at about $\$ 1,970$ in 1999, while in Estonia it was \$9,096-almost five times higher. Against this background it is assumed that whereas in Azerbaijan GDP will increase on average by 7 percent between 2000 and 2003, in Estonia it will grow by only 4.1 percent per year, yet its absolute production will remain much larger. As for Albania and Slovenia, the relevant GDP per capita on a PPP basis is $\$ 1,474$ and $\$ 14,267$, whereas the expected rates of growth are 7.1 percent and 4.2 percent. Therefore, according to the above logic, not surprisingly Albania and Azerbaijan can be found among the frontrunners, whereas the more developed Estonia and Slovenia will be among the gainers, and only at the very end of the league (Table 7).

These predictions must be seen as passive scenarios based on the extrapolation of recent trends and certain assumptions vis-à-vis future policy reforms. The recent forecasts are often less optimistic than those of only a couple of years ago. The change of mood results, inter alia, from negative external shocks, which have influenced not only the real economy, but even more the ways of thinking and expectations. For this reason, contrary to the early $1990 \mathrm{~s}$, it could happen that there may be excessive pessimism this time.

Yet it is true that the Russian "crisis within the crisis" and its 1998 financial climax has affected not only several FSU republics, but some other economies as well, including the previously faster growing Slovakia owing to the large exposure to trade with Russia. In other countries, e.g., Poland and Slovenia, deceleration of growth occurred more as a result of inconsistent policies and delayed structural reforms. As far as active financial policies are concerned, they can possibly bring back the pace of growth in these countries close to the 7 percent rate already accomplished. Maintaining growth at this level for many years will keep these economies among the frontrunners. This is possible and in fact is likely. Consequently, certain scenarios would soon change in a more optimistic direction. Forecasts depend mostly on the policies - not the other way around. 
Table 7. Transition Economies: Average Rate of GDP Growth in 2000-03(4)

(In percent)

\begin{tabular}{ll} 
Frontrunners & 10.7 \\
Yugoslavia & \\
Albania & 7.1 \\
Azerbaijan & 7.0 \\
Georgia & 6.2 \\
& \\
Gainers & \\
Slovakia & 5.5 \\
Armenia & 5.5 \\
Hungary & 5.3 \\
Poland & 5.2 \\
Romania & 5.1 \\
FYR Macedonia & 4.7 \\
Bulgaria & 4.7 \\
Lithuania & 4.3 \\
Turkmenistan & 4.3 \\
Bosnia-Herzegovina & 4.3 \\
Slovenia & 4.2 \\
Tajikistan & 4.2 \\
Estonia & 4.1 \\
Latvia & 4.1 \\
& \\
Even-runners & \\
Czech Republic & 4.0 \\
Moldova & 4.0 \\
Croatia & 4.0 \\
Kazakhstan & 4.0 \\
Kyrgyzstan & 3.4 \\
Ukraine & 2.4 \\
Russia & 2.1 \\
Laggards & \\
Uzbekistan & 1.8 \\
Belarus & 0.5 \\
\hline & \\
\hline
\end{tabular}

Source: Author's estimation based on the forecast of PlanEcon 1999a and $1999 \mathrm{~b}$.

${ }^{1} 2003$ for the FSU and 2004 for the EE economies. 
According to the above discussion, there can be four paths of long-term growth: for the laggards, even-runners, gainers and the frontrunners. The question is under which classification would a particular country fall if it were to stay the course of a specific pace of growth for a given period of time during the next 50 years? (Figure 2).

Within the above four hypothetical scenarios there are three subscenarios, i.e., the core scenario A, the minimum scenario $\mathrm{B}$, and the maximum scenario $\mathrm{C}$. The extreme subscenarios are based on a calculation of a half century of growth that is either at the minimum or at the maximum end of the band, the center of which is given by the core scenario A (Table 8).

The first scenario initially presumes a medium-term (five years) period of slow growth due to unstable fundamentals, weak institutions, an inadequate policy response, and negative external shocks. Then growth accelerates for the subsequent five years due to continuing institution-building and policy reforms as well as more favorable external factors, e.g., an end of regional conflicts. Later, over a full decade, acceleration gains momentum owing to institutional advancement and better policies stemming from learning by doing, experience and knowledge. Hence these economies advance to the gainers group, which means that their rate of growth increases to the range of 4 to 6 percent. Afterwards, for the long-term of three decades, growth declines, but only to the pace of even-runners, i.e., 3 percent. Thus in a matter of one generation the transition process lifts national income almost twofold, and over two generations by 2050 , growth may increase about five times. Considering the range of growth rates, in subscenarios $1 \mathrm{~B}$ and $1 \mathrm{C}$ cumulative growth could be much smaller or significantly larger than in the core scenario 1A (see Figure 2.1). This type of scenarios is likely for countries that have weak fundamentals, poor institutions, delayed structural reforms, inconsistent development policies, relatively less favorable geopolitical position, and in certain cases the countries might be directly or indirectly affected by local tensions and conflicts. For instance, countries like Tajikistan in the FSU, or Romania in the EE region fit to a certain degree in these scenarios. The future will bring a lot of mutations that will make the real picture even more colorful. Nevertheless, these countries can accelerate their rate of growth later too, if only through proper policies they will be able to get rid of various lingering structural and institutional bottlenecks keeping them thus far from attaining their growth potential.

The second scenario is for countries that will take only limited advantage of the opportunities brought by introduction of a market economy. For this reason their rate of growth will be even slower than under the centrally planned system. Moreover, sluggish growth will be accompanied by increasing inequality (Milanovic, 1998 and Kolodko, 1999c). For the first period, say, 15 years, these countries will grow at about 3 percent annually and then at an even slower rate of only 2 percent. Then, during a period of the second generation, a sequence of 15 years as even-runners, and ten years as laggards may be repeated. All these possibilities are probable for the countries that are still muddling through inconsistent structural reforms and burdened by an institutional vacuum. Old institutions have been already dismantled, but the new ones are not yet in place. Such a hybrid system contributes 
Fig.2.1 Alternative Growth Paths for the Very Long-Term, 2000-2050

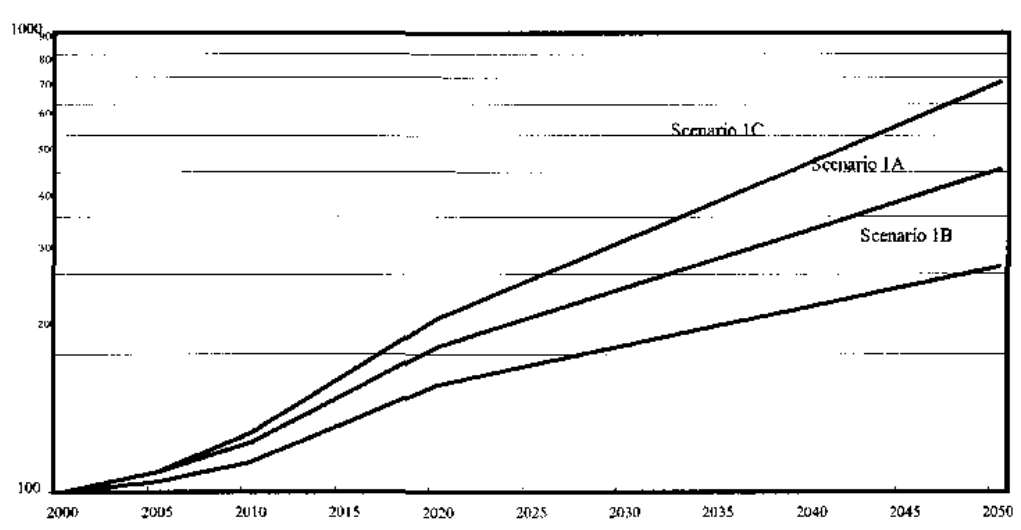

Fig.2.3 Alternative Growth Paths for the Very Long-Term, 2000-2050

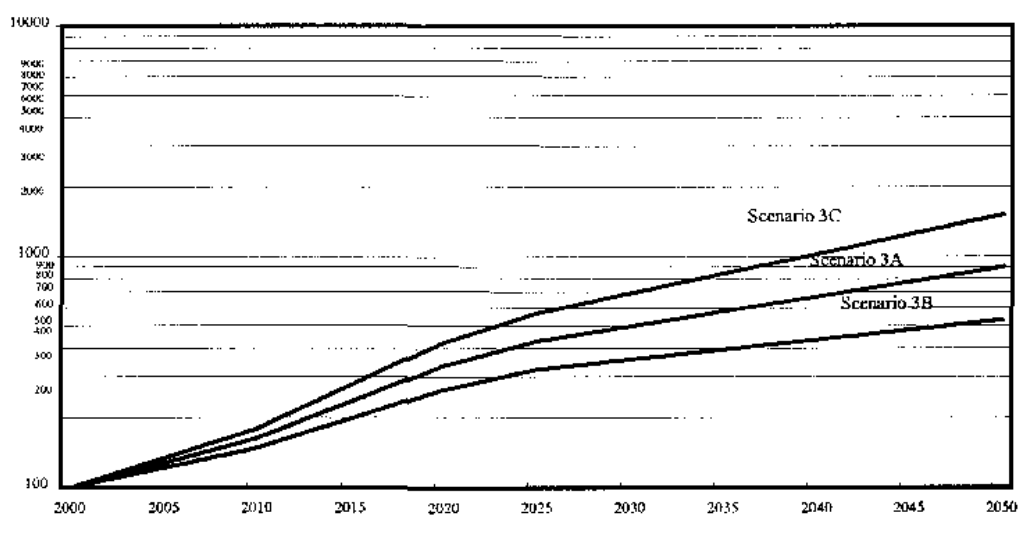

Fig.2.2 Alternative Growth Paths for the Very Long-Term, 2000-2050

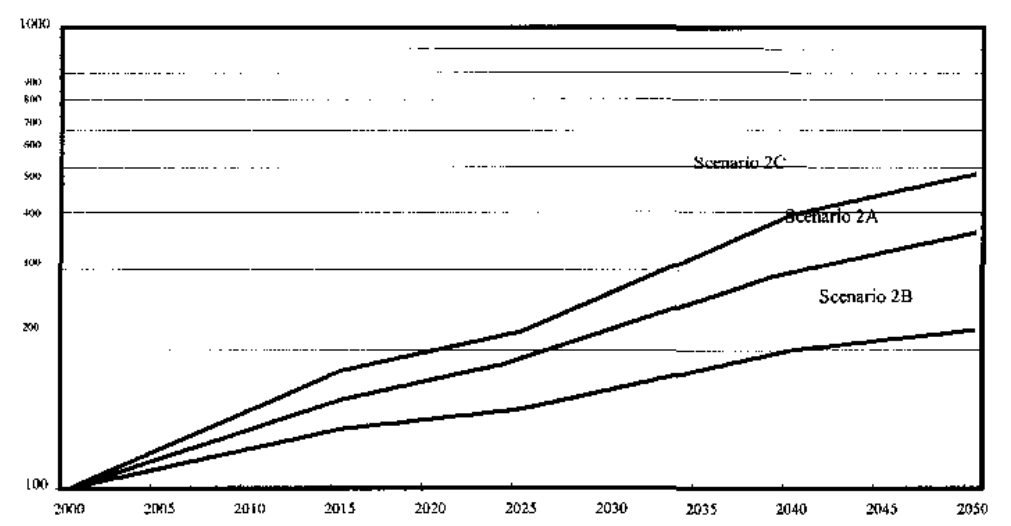

Fig.2.4 Altemative Growth Paths for the Very Long-Term, 2000-2050

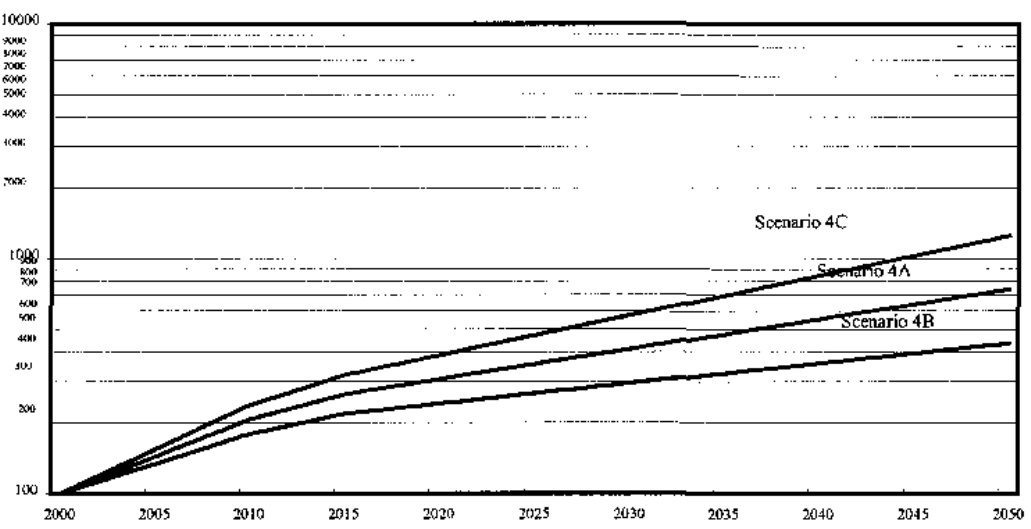


Table 8. Catching-up in the Transition Economies in the $21^{\text {st }}$ Century, 2000-2050

\begin{tabular}{|c|c|c|c|c|c|c|c|c|c|c|c|c|}
\hline Scenario & $1 \mathrm{~A}$ & $1 \mathrm{~B}$ & $1 \mathrm{C}$ & $2 \mathrm{~A}$ & $2 \mathrm{~B}$ & $2 \mathrm{C}$ & $3 \mathrm{~A}$ & $3 \mathrm{~B}$ & $3 \mathrm{C}$ & $4 \mathrm{~A}$ & $4 B$ & $4 \mathrm{C}$ \\
\hline \multirow[b]{4}{*}{ Year } & Laggard̋s-5 & & & Even-runners-15 & & & Gainers-10 & & & & & \multirow[b]{4}{*}{ Max. } \\
\hline & Even-runners-5 & & & Laggards-10 & & & Frontruners-10 & & & lirontrunners-10 & & \\
\hline & Gainers-10 & & & Even-runners- 15 & & & Gainers-5 & & & Gainers-5 & & \\
\hline & Even-rumers-30 & Min. & Max. & Laggards- 10 & Min. & Max. & $\begin{array}{c}\text { Even-runners- } \\
25 \\
\end{array}$ & Min. & Max. & Even-runners-35 & Min. & \\
\hline 2000 & 100 & 100 & 100 & 100 & 100 & 100 & 100 & 100 & 100 & 100 & 100 & 100 \\
\hline 2005 & 110 & 105 & 110 & 116 & 110 & 122 & 128 & 122 & 134 & 144 & 134 & 154 \\
\hline 2010 & 128 & 116 & 134 & 134 & 122 & 148 & 163 & 148 & 179 & 206 & 179 & 237 \\
\hline 2015 & 163 & 141 & 180 & 156 & 135 & 180 & 234 & 198 & 276 & 263 & 218 & 317 \\
\hline 2020 & 208 & 172 & 241 & 172 & 141 & 199 & 336 & 265 & 424 & 305 & 241 & 385 \\
\hline 2025 & 242 & 190 & 293 & 192 & 149 & 220 & 428 & 323 & 567 & 354 & 266 & 469 \\
\hline 2030 & 280 & 209 & 356 & 222 & 164 & 267 & 497 & 356 & 690 & 410 & 293 & 571 \\
\hline 2035 & 25 & 231 & 433 & 258 & 181 & 325 & 576 & 393 & 840 & 475 & 324 & 694 \\
\hline 2040 & 377 & 255 & 527 & 296 & 200 & 395 & 668 & 434 & 1022 & 551 & 357 & 845 \\
\hline 2045 & 437 & 282 & 641 & 327 & 210 & 437 & 774 & 479 & 1243 & 638 & 395 & 1028 \\
\hline 2050 & 506 & 311 & 780 & 361 & 221 & 482 & 897 & 529 & 1512 & 740 & 436 & 1250 \\
\hline
\end{tabular}

Source: Author's calculation. See text for the assumptions. 
to making growth more difficult and side tracks countries from the opportunity to catch up in just an illusion. Even if the geopolitical position helps and human capital is relatively strong, weak fundamentals and an unstable political situation can discourage domestic capital formation and hinder absorption of the flow of foreign savings. Thus in 2025 and 2050 this group of countries can be as far behind the average global income as they were in 2000 , because growth will rise only by about 260 percent over the very long-term (see Figure 2.2). What countries are likely to belong to this group, is left to the countries themselves to decide, since according to the logic of the reasoning presented, thus far no country is doomed a priori to such meager growth.

The third scenario reflects a situation in which over a period of ten years or so the average rate of growth is sustained at 5 percent, while oscillating between 4 and 6 percent. This may be plausible for the gainers that have strong institutions and improving fundamentals as well as a reasonable policy response and advanced structural reforms. During the succeeding decade growth may even jump to 7.5 percent and then decline one more time to 5 percent over the medium-term. After a time span of one generation, growth will slow down to the pace of the even-runners, where it may be maintained for another 25 years. This growth pattern would indeed be extremely successful. In this scenario the catching-up process would be complete, since at the end of the journey income would be at par with the standard of developed industrial countries. ${ }^{11}$ Perhaps, luck catching up may occur for the best performers among countries joining the EU soon. It is hardly imaginable that all of them will succeed in taking this path, yet the strongest performers seem to have a chance (see Figure 2.3). If so, realistically these countries should be a close fit to the minimum sub-scenario $3 \mathrm{~B}$, because the maximum one, i.e., $3 \mathrm{~A}$, would approach a postsocialist miracle. Of course, a miracle would help, the problem however is that the miracles do not happen neither in East Asia, nor in Eastern Europe.

The fourth scenario (see Figure 2.4) is very optimistic as well. And over sevenfold increase of real income during half a century has not happened that often in the course of history. Indeed, it has occurred very seldom (Cohen, 1998). Nonetheless, under certain circumstances this rapid rate of growth can be fulfilled in the case of the leading transition economies, on the one hand, and for some of the underdeveloped post-socialist countries. Other economies with strong fundamentals and matured institutions, say the members of OECD, can also aspire to the first group under the above scenario. They must simultaneously manage sound policies and take full advantage of their integration with the EU as well as attract a continuously large inflow of FDI. For instance, for Hungary or Poland among the EE emerging markets, or for Estonia in the FSU region, this scenario is not unimaginable. Their favorable geopolitical positions and quality of human capital can help too. Yet the decisive factors will be the policy strategies, particularly those enhancing entrepreneurship. Open product markets, flexible labor markets, and well-developed capital markets make it easier for entrepreneurs to start new firms. This kind of "venture

\footnotetext{
"Of course, only the income, that is the flow. As for the standard of living, which is a function of both the flows and stocks of assets accumulated in the past, this group of countries would still be firmly below the level enjoyed by most advanced societies.
} 
privatization" and grass-roots entrepreneurship are of critical importance for sustaining a high-speed rate of growth (Lavigne, 1999; Kolodko, 2000b). In the first decade of the $21^{\text {st }}$ century these types of economies would grow as the frontrunners, having an average growth rate at about 7.5 percent. In such a case GDP would double over ten years; this is two times sooner than under the first scenario. Later, when the catching-up process will have advanced, the rate of growth would decline to 5 percent or so and then would fall to the EU level.

But this scenario can also match the characteristics of other types of economies, which start from a very low income base. Despite weak institutions and unstable fundamentals, despite lagging structural reforms and often not the most reasonable policy responses, these economies can nevertheless take off towards this kind of catching-up too. That is because of the coincidence of two specific factors, which before many other features that facilitate fast growth, and do matter for the catching-up process. On one hand, the nascent fruits of transition, i.e., liberalization and privatization, are contributing to fast growth in countries at a very low starting point because of improved capital inflow and its better allocation. On the other hand, valuable natural resources will attract a strong FDI flow boosting strong growth for several years. For instance, Azerbaijan fits into this category well and, to a lesser extent, so does Tajikistan. Their level of development gives them a better chance to grow quickly, since they start from a GDP per capita, on a PPP basis, of only $\$ 1,970$ and $\$ 750$, respectively. If only other conditions are met, particularly if there is a conclusive end to regional conflicts, then these countries can indeed take off towards fast growth.

Later, after these two different groups of post-socialist economies have significantly upgraded their level of development over the next 15 years or so, their economies will expand at different paces. The advanced ones should slow down to the pace of even-runners for the following 35 years. Most likely then they will be closer to the lower limit within the band of a 2 to 4 percent rate of annual growth. The less developed countries will be closer to the upper limit, that is, to 4 percent, or they may even match the higher rate of growth that characterizes the gainers. In this scenario, as in scenarios two and three, the critical catchingup occurs at the beginning and during the middle years of the whole period, whereas toward the end of the cycle the rate of growth is supposed to be basically on the par with the more advanced countries and this would be only for the countries starting from a very low level currently.

Yet it can happen that the entire process of catching-up will fail if structural reforms and institution-building do not perform at the base levels. It can fall short, if the political climate switches to an adverse situation. Catching up may be deferred, if globalization gets off-course and instead of streamlining transition hampers it. The true future of post-socialist economies will be much more complicated than that outlined in these hypothetical scenarios.

It is extremely unlikely that any country will stay an unchanged course over the very long run, say for a generation or two. Countries may switch often from one path of growth to another. They will do so in both directions, which means up and down, depending on the changing domestic and international conditions. Some will not be able to avoid a threat of recession, when they are confronted by external shocks or by their own policy excesses. 
Many of these changes are completely unpredictable now. Many others will be a matter of political decisions taken — or not taken. This in turn will depend on the institutional aspects of development and the performance of democracy. Of course, the latter is also capricious, especially in the nations with relatively young democratic regimes, as indeed all postsocialist countries are.

Whereas for some countries future development will be about sustaining the path of growth they have undertaken, while for others the struggle will focus on getting to a path that will move their economies forward at a faster pace (Lucas, 1999). The future of postsocialist economies depends on selecting and committing to a favorable path of economic growth and the ability to stay the course for the longest possible time. A number of scenarios for further development are feasible. In the hypothetical occurrence of the extreme cases--which is simply unlikely - certain post-socialist economies could expand for the whole period of half a century as frontrunners or they could drag as laggards. This is hardly likely to happen, since we should not expect any economy to run on an average growth rate of 7.5 percent until 2050 , nor should we be pessimistic that there will be countries whose output will increase by very low margin, say just 1 percent per year, if at all. It should be expected that the transition economies will not belong to either of the extreme groups, but to the central one, that is, to the gainers and the even-runners. This implies that they will manage to stay on the course of a rate of growth that is appropriate to these two groups, that is, between 2 and 6 percent. However, within this very wide band it can be expected that most often the growth rate will fluctuate between 3 and 5 percent.

\section{ACtive Policies for Catching-UP in the $21^{\text {ST }}$ Century}

While looking into the future, it is necessary to distinguish between passive scenarios and active strategies. Along what path travel toward the future goes, will depend on many variables. Some of them are given and hence we can only try to foresee them more or less accurately and clearly. However, the critical mass of events in the growth process is contingent on chosen policies and the political will to follow the strategies. Once again the geopolitical position, inherited culture, quality of human capital and skilled labor, population and thus the scope of products and service markets, stock of natural resources, the beauty of the country and its attractiveness to tourists - all of these given factors matter for growth prospects. Some factors are permanent, some can be changed only over a long time period and only under the conditions of a growing economy. But what matters most, is the policy framework. Without a sound strategy even the areas of comparative advantage will not serve the purpose to advance development.

Countries with better geopolitical positions have the advantage of proximity to the major trade and financial markets, as Estonia does with Scandinavia, the Czech Republic to Germany, Bulgaria to Turkey, or even Azerbaijan to Iran, or Kyrgyzstan to China. These countries are finding themselves in a relatively better situation for faster growth now. Still more so do the countries aiming at integration with the European Union. Countries with a true commitment are carrying out gradual institution-building. For instance, Hungary and 
Poland will benefit from this strong foundation in the years to come, more so than other emerging markets. They are already benefiting from this investment.

The combination of these two factors - that is, the favorable geopolitical position in Eastern Europe and substantial progress vis-à-vis institution-building-are already boosting growth of the candidates for accession to the EU. These countries, even if relatively more developed, such as the Czech Republic, Estonia or Slovakia, will grow faster than other countries in the region. The entire group of countries can be foreseen in the next decade or two to be among the gainers. Some of them, under wrong policies or unfavorable external shocks, may be downgraded to the lower league. Yet before they catch up with Western Europe - or at least with the relatively less advanced southern part of Europe- they should not remain in these circumstances for too long. This means that even if from period to period they do not succeed in sustaining the rate of growth at about 5 percent annually, they can return to this path soon afterwards.

As for the countries that occasionally advance to the upper league, they will come from two different groups. The first will include the true leaders of transition, those that are able to combine sound development strategies with comprehensive structural reforms. These are two different, yet strongly inter-related issues. Healthy institutions brought up by structural reforms and improving market culture are not substitutes for good policy or a wise development strategy. They are complementary. In transition economies there is no straightforward cause of relationship between structural reforms and development. At least from the record of the first decade of transition, there is no clear indication that any such relation has been set in motion yet. Since this relationship does not work automatically, it must become a direct concern of the government policy.

So far there have been only three cases of high-speed growth that deserve to be counted as front-runners. However, this situation only lasted for a while. Estonia in 1995-97 (three years) and Poland in 1994-97 (four years) were growing at an average rate of 6.3 percent. Slovakia was able to follow suit at a latter period with a 6.2 percent growth rate. All three of these countries, as well as others working out their way to the EU, have a chance to repeat these accomplishments in the future. It calls for good coordination of fiscal and monetary management, well-designed industrial and trade policies, and subordination of structural reforms to a pro-growth policy. It calls also for proper institutions of conflict management, i.e., the ability to manage the distributional conflicts in the society, which can emerge during a time of adjustment to external shocks or other kind of surprising events (Rodrik, 1999).

The problem is that across the region of the FSU and EE the governments tend to neglect this latter aspect of long-term growth. This occurs because governments are often advised (and they tend to follow such guidance eagerly) that further reforms, particularly full liberalization and privatization, will do the job. Later, when these reforms are unfortunately not undertaken, the postponement of structural reforms is blamed for the "unexpected" underperformance. And if there is no way to accelerate these reforms owing to political and social constraints, the external shocks are then named as an excuse for the failures vis-à-vis growth policy. From this angle the Russian financial crisis of 1998-2000 has come to the 
rescue of many governments in transition countries, as well as their foreign institutional and individual advisors, because it serves the purpose of a scapegoat extremely well.

The second group that advances periodically to the frontrunners will come from the less developed post-socialist economies, which literally are catching-up with their more advanced neighbors. If these countries take advantage of foreign aid, which in some cases is not negligible (e.g., in Albania and Bosnia-Herzegovina), their economies can run forward quickly. This did happen during the first decade of transition, and it will occur more often over the next decades. Bosnia-Herzegovina had an unusual, soaring rate of growth of over 40 percent on average in 1996-98, but this was due to the post-war recovery entirely financed from external sources, mainly grants. Albania in 1993-96 had an average rate of growth of 9.2 percent. In Georgia in 1996-97 GDP increased by 10.2 percent annually. Similarly in Azerbaijan, the average rate of growth was 7.9 percent in 1997-98.

However, all these semi-catching-up processes became unsustainable in the face of too weak fundamentals, poor institutions, inconsistent policies and negative external shocks. Hopefully this will change again, and this time in the right direction. Already, for the latter three countries very high rates of growth are predicted for the early $2000 \mathrm{~s}$ and not without good reason. All of them-plus Yugoslavia recovering from the 1999 war devastation — can turn into the frontrunners for some period of time (see Table 7). If even this happens one more time it will not be a guarantee of fast growth for very long. This would require active policies: coordinated properly with the structural reforms and development strategy, be carried out.

For simple, computation reasons small differences vis-à-vis the rate of growth become large in the very long-term. When considering the next half century only one point of difference between 3 and 4 percent annual rates of growth adds as much as 272 percentage points on a cumulative basis. That is enough to catch up and close the large gap. For instance, if a country like Hungary starts from a current GDP of about $\$ 5,500$ (on a market exchange basis) and is able to sustain it for the next 50 years at 4 percent rate of growth, it would bring GDP up to as much as $\$ 39,000$. This is more than today's GDP of the United States. If Hungary's GDP would grow only by 3 percent over the next five decades, then in 2050 its per capital income will be "only" about $\$ 24,000 .{ }^{12}$ This is hardly enough to catch up with the moving average of EU countries, because by then it will have exceeded

\footnotetext{
${ }^{12}$ However, it is more rational to consider for the purpose of catching-up that GDP measured in terms of purchasing power parity. Therefore, in Hungary's example, the respective values would be $\$ 57,000$ and $\$ 35,000$. There are certain methodological concerns about the relevance of the data used for the purpose of these comparisons. Always the evaluation of GDP based on purchasing power parity ought to be taken with caution, and even more so as a proxy for the transition economies. It must raise some doubts if the evaluation of GDP per capita (in 1995 PPP dollars) suggests that Estonia is on the par with the Czech Republic, or that Belarus' income is almost twice as large as the Ukraine's, or that Macedonia's GDP per capita is almost 70 percent larger than Moldova's. However, these estimations are made on the same methodological grounds and are done along the lines of similar assumptions. So if
} 
$\$ 50,000-$-even if over the next 50 years it were to grow by a mere 2 percent annually. So one percentage point indeed makes a difference. And when the higher rates of plausible growth are taken into account, the larger the gap becomes.

What a particular country's GDP per capita will be in the future, depends on its value at the point of departure in 2000 and its pace of growth over the next decades. Assuming that the GDP per capita, on a PPP basis, in the most advanced industrial countries is approximately $\$ 30,000$, how many times must the current level of GDP in transition economies increase to match this? The specter of the multiplying factor in this regard is quite large: from about two times in the case of the most advanced post-socialist economy, that is Slovenia with GDP per capita at around $\$ 14,800$, to as much as 39 times in the case of the most underdeveloped country, Tajikistan with a GDP per capita of about $\$ 770$. Whereas only for eight countries is the ratio no larger than 5 to one, in 12 cases it is believed to be no less than 10 to one (Figure 3).

Actually, many post-socialist countries are not that far behind the countries with the highest GDP per capita as the data on GDP for OECD countries suggest. Gross domestic product is just a flow of current production and does not reflect other important aspects of the standard of living. In transition economies - this time the legacy from the centrally planned period is positive - there is a high, on par with the OECD countries, life expectancy. The rate of literacy is very high, secondary school enrollment is similar to the advanced industrial societies, etc. This has significant implications for the future not only because it shows that the quality of human capital and hence the growth potential are relatively higher than other developing economies.

It also shows that if growth in terms of quantity supplied can be considered as a linear process, it is not so with socio-economic development. In future the model of development will change, and the measures of development will evolve too. They will take more account of the quality of human capital, standard of natural environment, access to culture and nature, density of urban areas and other issues that are omitted from the current GDP index. Some of the items that thus far are included, and hence suppose a rise in the standard of living in due time may be considered as an obstacle to this end. Therefore, the catching-up process may take a shorter time than can be seen through the prism of catching-up with the quantity of output.

It would be more reasonable for the purpose of catching-up to sustain a stable yet relatively high rate of growth for a very long period of time, than to attempt maximization over a predetermined time period, which will approach its outer limits sooner than expected. In such a case, owing to the risks involved and the likelihood that the economy may get out of balance and consequently slow down, even if for only a couple of years, the final result may be less impressive. In other words, it is a better strategy to be the gainer all the time

there is--and for sure there is-some error in these estimations, it still allows us to rely with proper reservations, on these data. 
Figure 3: Catching-up with the Developed Countries

How Many Times Should Output Rise to Catch Up with a PPP of $\$ 30,000$ GDP Per Capita

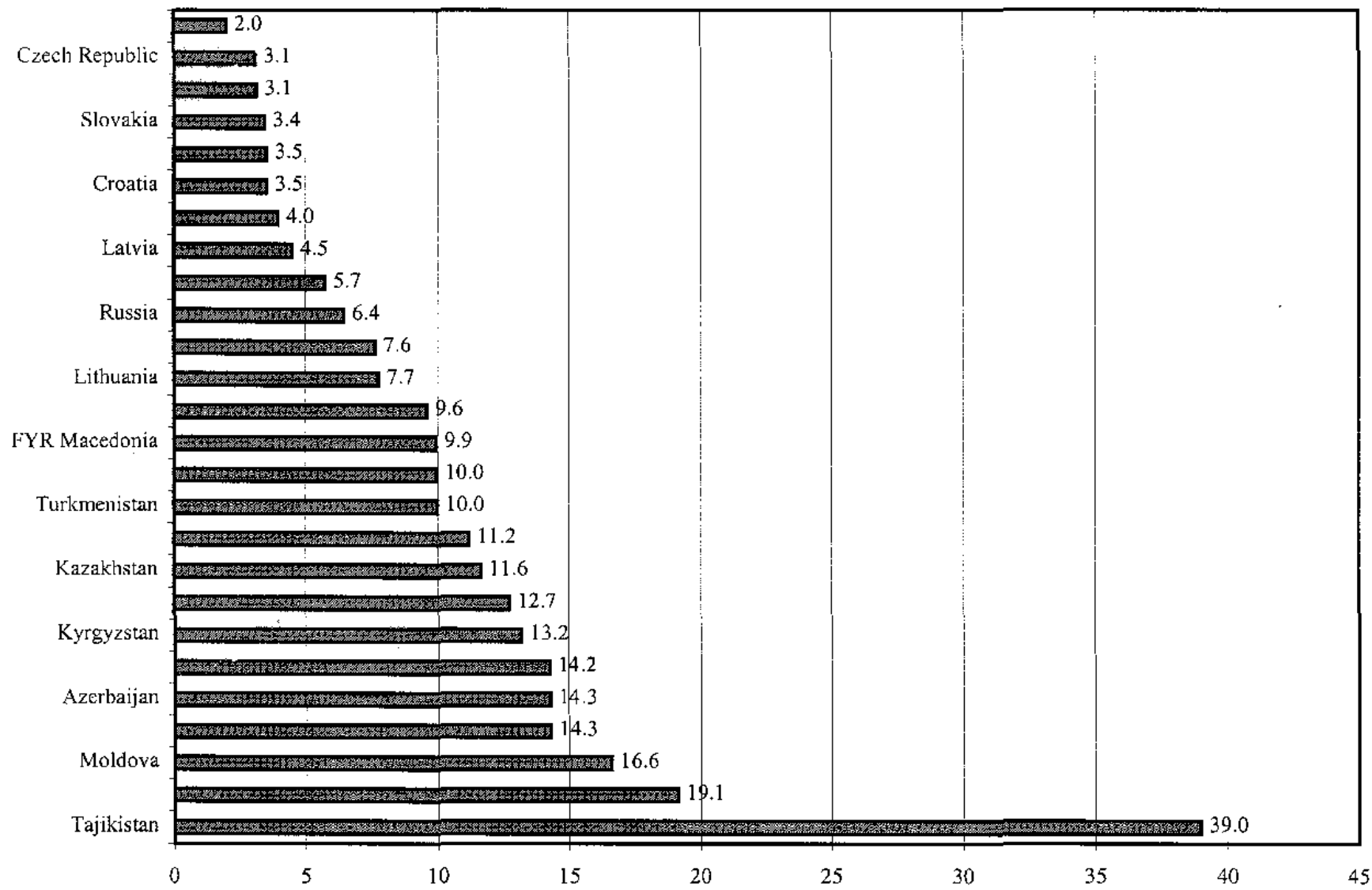


than to be a frontrunner for a while, but at the price of later on becoming an even-runner, or possibly a laggard.

As a consequence of all these circumstances, particular post-socialist countries will be able to catch up with the level of output of the developed world though in very different years. Of course, the latter countries are growing economies too, so catching-up should be seen as running toward a forward-moving target. Yet to get to the current level of production of the world leaders would be quite an achievement. In what year might this happen? It depends on the path of growth: will the transition economies be more like frontrunners or even-runners? The laggards, of course, do not count (Table 9).

All these paths show how long is the distance to be overcome to catch up and close the development gap. This gap has widened not only during times gone by but unfortunately it has deepened even more during the last decade of the $20^{\text {th }}$ century. The gap may be eliminated not in half a century, but perhaps over several centuries, if at all. Catching-up with the advanced industrial countries is not an imperative for the transition economies. It is only an option and a chance that can be taken or lost - as has happened so many times in the history of mankind.

The post-socialist countries must try to find their own path toward growth, one that will enable them to advance in the catching-up process as much as feasible. Only this will make sense out of the whole transition and turn it into its ultimate success. Such success is contingent on patience, good policies and years of hard work.

\section{Policy Conclusions}

There is time to ask one more essential question: are all the foregoing analyses and conclusions correct, and especially are the forecasts reasonable, especially since they turned out to be wrong so many times in the recent post-socialist past? The answer consists of three parts. First, there were many warnings and predictions that accurately pointed to the risks and future unpleasant occurrences, yet they were not taken sufficiently into account by the policymakers, including international organizations. Second, theoretical assumptions that the transition countries can become fast growing economies are correct, nonetheless the conditions for such a take-off were not fulfilled earlier, also due to policy failures. And third, now is the time to proceed rationally and develop policies that create the conditions, in which growth can accelerate. There are the differences and there are the risks.

One difference between then and now is that now we are supposed to know much better than at the initial stages what works in post-socialist economies and why, and what does not work and why. Although the risk remains, the false assumption suggesting that unleashed market forces can still take over and effect the needed development programs, we should already know that this is not the case. For this reason governments' sound development strategies and the wise involvement of the international community, including official and nongovernmental organizations, must support the market forces. 
Table 9. Transition Countries: The Year of Catching-Up with the Developed Countries (In U.S. dollars and calendar years)

\begin{tabular}{|c|c|c|c|c|}
\hline & \multirow{2}{*}{$\begin{array}{c}\text { GDP Per Capita } \\
\text { In } 2000 \\
\text { (in } 1995 \$ P P P \text { ) }\end{array}$} & \multicolumn{3}{|c|}{$\begin{array}{l}\text { The Year of Catching-up with the GDP Per } \\
\text { Capita of } 30,000 \$ P P P\end{array}$} \\
\hline & & Front-Runner & Gainer & Even-Runner \\
\hline Albania & 1,569 & 2041 & 2060 & 2100 \\
\hline Armenia & 3,009 & 2032 & 2047 & 2078 \\
\hline Azerbaijan & 2,101 & 2037 & 2055 & 2090 \\
\hline Belarus & 5,238 & 2024 & 2036 & 2059 \\
\hline Bulgaria & 3,930 & 2028 & 2042 & 2069 \\
\hline Croatia & 8,484 & 2017 & 2026 & 2042 \\
\hline Czech Republic & 9,699 & 2016 & 2023 & 2038 \\
\hline Estonia & 9,606 & 2016 & 2023 & 2038 \\
\hline FYR Macedonia & 3,017 & 2032 & 2047 & 2077 \\
\hline Georgia & 2,099 & 2037 & 2055 & 2090 \\
\hline Hungary & 8,525 & 2017 & 2026 & 2042 \\
\hline Kazakhstan & 2,576 & 2034 & 2050 & 2083 \\
\hline Kyrgyzstan & 2,279 & 2036 & 2053 & 2087 \\
\hline Latvia & 6,681 & 2021 & 2031 & 2051 \\
\hline Lithuania & 3,872 & 2028 & 2042 & 2069 \\
\hline Moldova & 1,805 & 2039 & 2058 & 2095 \\
\hline Poland & 7,575 & 2019 & 2028 & 2047 \\
\hline Romania & 3,124 & 2031 & 2046 & 2076 \\
\hline Russia & 4,654 & 2026 & 2038 & 2063 \\
\hline Slovakia & 8,707 & 2017 & 2025 & 2041 \\
\hline Slovenia & 14,802 & 2010 & 2014 & 2024 \\
\hline Tajikistan & 770 & 2051 & 2075 & 2124 \\
\hline Turkmenistan & 3,004 & 2032 & 2047 & 2078 \\
\hline Ukraine & 2,357 & 2035 & 2052 & 2086 \\
\hline Uzbekistan & 2,681 & 2034 & 2048 & 2082 \\
\hline Yugoslavia & 2,108 & 2037 & 2055 & 2090 \\
\hline
\end{tabular}

Sources: The 2000 GDP per capita from PlanEcon 1999a and 1999b. Forecasts are the author's own calculations. 
A second difference between then and now is that at the onset of the new century all transition economies are already growing albeit at different rates. So the question is no longer how to stop recession and depression, but how to accelerate the rate of growth and sustain it at the highest possible level for the longest possible period. There is always the challenge of how to do it within the framework of the specific institutional arrangements and political environment of the nascent post-socialist markets and democracies. Negligence of this specificity creates the second risk.

Policies exercised during the first decade of transition to a large extent have been derived from the so-called Washington consensus, though this set of structural reforms was designed for another challenge (Williamson, 1990 and 1997). When the policies were applied to the post-socialist economies, they greatly influenced the direction of systemic reforms and the course of change (Stiglitz, 1998). However, the transition has also had a significant counter-impact. The policies have not generated the anticipated results, and this has led to a search for alternative measures (Kolodko and Nuti, 1997). As the post-socialist markets have emerged, so have fresh issues, problems, and concerns. The reactions to these concerns have differed, and new approaches have evolved. Following a number of conclusions and policy options formulated so far, another ten major policy conclusions must be put forward here (Kolodko, 1999a).

First, institutional arrangements are the most important factor in the achievement of fast and durable growth. They should be established through a process directed by government (by design) rather than spontaneously (by chance). In those nations in which government has been committed to this approach, recovery has come sooner, growth has been more robust, and prospects for sustainable development are greater. Those countries in which government has relied on the spontaneous appearance of new institutions have not been able to manage this complex process adequately and are lagging behind both vis-à-vis systemic transition and in growth of the real economy. Institution-building must be a gradual process. The effects of specific inputs in this process must be constantly monitored, and policies be regularly adjusted and corrected. One should not depend on the experiences in distorted market economies, but should understand the special features of the emerging postsocialist markets. This is especially true in matters related to privatization and the development of capital markets.

Second, the size of government is less important than the quality of government policies and the manner in which the changes are implemented (Tanzi, 1997). In transition economies a profound restructuring of the public finance system is more important than is the downsizing of government. Fiscal transfers should be redirected from noncompetitive sectors towards institution-building (including behavioral and cultural changes) and investments in human capital and hard infrastructure. Attempts to downsize government through expenditure cuts can do more harm than good in terms of recovery from transitional recession and the achievement of sustained and fast growth. Even if one believes that small government is better than big government (which usually is true), to downsize may lead to 
economic contraction and deterioration in standards of living. Expenditures should not be cut for the sake of the illusion of fiscal prudence, but should be restructured.

Third, if institutional arrangements are neglected and left to spontaneous processes and liberalized market forces, then there will be a systemic vacuum and "informal institutionalization" will occur. Spreading corruption and organized crime are extreme examples of informal institutionalization. These are the two principal diseases in countries in which liberalization and privatization have taken place under weak government.

Governments may sometimes be too weak because they are too big, but in transition economies they are often too weak because they have been downsized too soon, before the emerging market and NGOs were able to take over relevant functions from the state. Even if the aim of the downsizing is to reduce the scope of fiscal redistribution so as to encourage capital formation and hence investment and growth, one must not overlook the fact that the struggle against informal institutions is costly in fiscal terms, too. A prematurely or too thoroughly downsized government may not be strong enough to lead in this struggle, and the market may quickly expand within the informal sector, while difficulties are mounting in the official economy. Thus, profits accrue to the informal sector, while revenues drop in the official sector. Profits are thereby "privatized," while loses are "socialized" in a politically unsustainable process full of negative consequences for the budget and for social policies.

Fourth, in transition economies policies must aim at transforming and streamlining the legal system so that it can serve the market economy. The establishment and development of new laws - trade and tax codes, capital market regulations, the protection of property rights, antitrust regulations, banking supervision, consumer protection, environmental protection - are extremely important and ought to be addressed before state assets are fully privatized. The establishment of a legal framework appropriate to the market economy should be much higher on the agenda of international financial organizations. It must be a more urgent and important issue than trade liberalization and assets privatization, since the latter can contribute to sound growth only if the former has been assured.

Fifth, a shift in functions from the central government to local governments is necessary for deregulation in the post-socialist economy. This means that some decentralization must be undertaken in the public finance system and that local governments must be given more fiscal autonomy. The process of taking functions away from the central government must be matched by reinforcing local governments. Both levels of government must be seen as two parts of a single entity, which is essential for gradual institution building. If local governments are not strengthened as the central government is reduced, then healthy market forces cannot be supported by new institutional arrangements, and liberalization and privatization are less likely to improve capital allocation and raise efficiency.

Sixth, the development of nongovernmental organizations must be accelerated. More significantly, international technical and financial assistance must be channeled into the effort to empower nongovernmental organizations. Along with the private sector and the state, these organizations are an indispensable third pillar of the contemporary market economy and civic society. A wide range of nongovernmental organizations active in various areas of public life is needed to ease the constant tension between the state and 
society. The expanding private sector alone cannot adequately fill this gap. Certain areas of public life cannot rely on the state, or on the business-oriented private sector. Without the institutional infrastructure provided by nongovernmental organizations, successful systemic change and high-quality growth become more problematic, and the infant market economy and democracy in post-socialist nations cannot evolve properly, and transition will be incomplete.

Seventh, income policy and equitable growth are very important for growth sustainability and thus for the ultimate success of the transition. Because increasing inequity is unavoidable during the initial years of transition, the state, through fiscal and social policies, must play an active role in managing income dispersion. Beyond a certain limit, income disparities inhibit the expansion of economic activity, delay recovery, and slow down economic growth. Substantial inequities hamper crucial institutional and structural reform.

Eighth, the post-socialist transition to the market is taking place in a context of worldwide globalization. Hence integration with the world economy is an indispensable part of the process. This must be managed carefully. Special attention must be paid to short-term capital liberalization, which must be monitored and controlled by fiscal and monetary authorities and supported by international financial institutions. It is better to liberalize capital markets later rather than sooner. Institution building must first be sufficiently advanced, and stabilization measures already ought to be consolidated and stable. Only then should financial markets be liberalized in a gradual manner. Otherwise the populations in the young and emerging democracies will not back the introduction of market mechanisms or integration with the world economy and they may even become hostile to these steps.

Ninth, international organizations should not only support globalization, but ought to encourage regional integration and cooperation. Fast and durable growth requires export expansion, which depends on strong regional linkages. In turn, this calls for institutional support through import-export banks, commodity exchanges, credit insurance agencies, and so on. This should be the main focus of the institution-building effort of the EBRD through its direct lending and technical assistance. This sort of market infrastructure is now underdeveloped in transition economies, and regional trade and direct cross-country investment are lagging behind in the process of changes. What should be a driving force behind sustainable growth is actually now a major obstacle.

Tenth, the Bretton Woods institutions should reconsider their policy approach towards transition economies. While the IMF should emphasize financial liquidity, currency convertibility, and fiscal and monetary stabilization, the World Bank should focus mainly on supporting equitable growth and sustainable development. These two areas of economic policy are frequently at odds. There is a tendency to confuse the means and the ends of policy, to favor short-term stabilization over long-term growth and development. Decision makers should not rely only on stabilization policies, but should seek a proper balance between stabilization policies and medium- and long-term development strategies. Fiscal and monetary policies must be subordinated to development policy - not the other way around. The World Bank performance criteria for socio-economic development are needed 
as much as are the IMF fiscal and monetary criteria. An eye should always be kept on the impact of financial policies in terms of growth, capital allocation, income distribution, and the social safety net.

As conditions change and challenges appear, policies must be revised in the future too. Consequently, the quest for a comprehensive and achievable policy consensus, which facilitates sustained and fast growth, must be ongoing. Especially since there is the occasion to catch up. Such a chance should not be lost. 


\section{REFERENCES}

Alesina, Alberto (1997), "The Political Economy of High and Low Growth," in Boris Pleskovic and Joseph E. Stiglitz (eds), Annual Bank Conference on Development Economics 1996 (Washington: World Bank), 217-37.

Bauer, T'amas (1978), "Investment Cycles in Planned Economies," Acta Economica, xxi, March, 243-60.

Blejer, Mario I., and Marko Skreb (eds.) (2000), "Transition. The First Decade," Kluwer Academic Publishers (forthcoming).

Borensztein, Eduardo and Peter J. Montiel (1991), "Savings, Investment, and Growth in Eastern Europe," in Georg H. Winckler (ed.), Central and Eastern Europe Roads to Growth (Washington: International Monetary Fund and Austrian National Bank), 153-87.

Cohen Daniel (1998), "The Wealth of the World and the Poverty of Nations" (Cambridge: Massachussets Institute of Technology).

EBRD (1997), “Transition Report 1997: Enterprise Performance and Growth,” (London: European Bank for Reconstruction and Development).

(1999), "Transition Report 1999: Ten years of transition," (London: European Bank for Reconstruction and Development).

Economist (2000), "Ex-Soviet Union. A Ghost Lurks," The Economist, January $29^{\text {th }}$, p. 60.

Fischer, Stanley, Ratna Sahay, and Carlos A. Vegh (1997). "From Transition to Market: Evidence and Growth Prospects," in Salvatore Zechinni (ed.), Lessons from the Economic Transition. Central and Eastern Europe in the 1990s, Dordrecht: Kluwer Academic Publishers, 79-102.

Gomulka, Stanislaw (1990). "Stabilizacja i wzrost: Polska 1989-2000" ["Stabilization and Growth: Poland 1989-2000"], in Grzegorz W. Kolodko (ed.), Polityka finansowa nierownowaga - stabilizacja (II) [Financial Policy - Disequilibrium - Stabilization (II)] (Warsaw: Research Institute of Finance), 303-21.

IMF (1991), World Economic Outlook (Washington: International Monetary Fund, May).

(1992), World Economic Outlook (Washington: International Monetary Fund, October).

(1999), World Economic Outlook, (Washington: International Monetary Fund, October).

Kolodko, Grzegorz W. (1976), "Economic Growth Cycles in the Centrally Planned Economy: The Case of Poland," Working Papers (Warsaw: Institute for Economic Development, Warsaw School of Economics (SGPiS)).

(1991). "Inflation Stabilization in Poland: A Year After," Rivista di Politica Economica, 6 (June), 289-330.

(1992a), "Economics of Transition: From Shortageflation to Stagflation, the Case of Poland," in Armand Clesse and Rudolf Tökes (eds), Preventing a New East-West 
Divide: The Economic and Social Imperatives of the Future Europe (Baden-Baden: Nomos Verlagsgesellschaft), 172-81.

(1992b), "From Output Collapse to Sustainable Growth in Transition Economies: The Fiscal Implications" (Washington: International Monetary Fund, December).

(1999a), "Ten Years of Postsocialist Transition. Lessons for Policy Reform," Policy Research Working Paper, 2095 (Washington: The World Bank, April).

(1999b), "Fiscal Policy and Capital Formation in Transition Economies", EMERGO. Journal of Transforming Economies and Societies, Vol. 6, No. 3 (Summer), 33-62.

(1999c), "Equity Issues in Policymaking in Transition Economies," in Vito Tanzi, Keyoung Chu, and Sanjeev Gupta (eds.), Economic Policy and Equity (Washington: International Monetary Fund), 150-88.

(1999d), "Transition to a Market Economy and Sustained Growth. Implications for the post-Washington Consensus," Communist and Post-Communist Studies, Vol. 32, No. 3, (September), 233-61.

(2000a), "From Shock to Therapy. The Political Economy of Postsocialist Transformation" (Oxford: Oxford University Press).

(2000b), "Transition to a Market and Entrepreneurship. The Systemic Factors and Policy Options," Communist and Post-Communist Studies, Vol. 33, No. 2, (June), 271-93.

Kolodko, Grzegorz W. and Walter W. McMahon (1987), "Stagflation and Shortageflation: A Comparative Approach," Kyklos, xl, 2, 176-97.

Kolodko, Grzegorz W., and Domenico M. Nuti (1997), “The Polish Alternative: Old Myths, Hard Facts, and New Strategies in the Successful Transformation of the Polish Economy." Research for Action, 33 (Helsinki: UNU/WIDER).

Kornai, Janos (1986), "The Hungarian Reform Process: Visions, Hopes, and Reality," Journal of Economic Literature, xxiv, 4, 1, 687-737.

Kozminski, Andrzej K. (1993), "Catching Up? Organizational and Management Change in The Ex-Socialist Block" (Albany: State University of New York Press).

Lavigne, Marie (1999), "The Economics of Transition: From Socialist Economy to Market Economy," (second edition), Chatham, Kent: Macmillan.

Lucas, Robert E. (1999), "Some Macroeconomics for the $21^{\text {st }}$ Century" (Chicago: University of Chicago, September) mimeo.

Milanovic, Branko (1998), "Income, Inequality, and Poverty during the Transition from Planned to Market Economy" (Washington: World Bank).

Montes, Manuel, and Vladimir Popov (1999), "The Asian Crisis Turns Global," (Singapore: Institute of Southeast Asian Studies).

Mundell, Robert A. (1997), "The Great Contractions in Transition Economies", in Blejer, Mario I. and Marko Skreb (eds.), Macroeconomic Stabilization in Transition Economies (London: Cambridge University Press), 73-99. 
North, Douglass C. (1997), "The Contribution of the New Institutional Economics to an Understanding of the Transition Problem," WIDER Annual Lectures, 1 (Helsinki: UNU/WIDER, March).

Nuti, Domenico M. (1992), "Lessons from Stabilization and Reform in Central Eastern Europe," CEC Working Papers, 92 (Brussels: Council of the European Community, May).

PlanEcon (1999a), "Review and Outlook for the Former Soviet Republics," (Washington: PlanEcon, Inc., October).

(1999b), "Review and Outlook for the Eastern Europe" (Washington: PlanEcon, Inc., December).

Poznanski, Kazimierz (1996), "Poland's Protracted Transition: Institutional Change and Economic Growth," (Cambridge: Cambridge University Press).

(1997), "Comparative Transition Theory: Recession and Recovery in Post-Communist Economies," conference paper presented at "Transition Strategies, Alternatives, and Outcomes," Helsinki: UNU/WIDER, 15-17 (May).

Rodrik, Dani (1999), “The New Global Economy and Developing Countries: Making Openess Work", Washington: Overseas Development Council.

Stiglitz, Joseph E. (1998), "More Instruments and Broader Goals: Moving towards the PostWashington Consensus," WIDER Annual Lectures, 2 (Helsinki: UNU/WIDER (January)).

Summers, Lawrence (1992), "The Next Decade in Central and Eastern Europe," in Christopher Clague and Gordon C. Rausser (eds.), The Emergence of Market Economies in Eastern Europe, Cambridge, Ma. and Oxford UK: Blackwell, 25-34.

Tanzi, Vito (1997), "Reconsidering the Fiscal Role of Government: The International Perspective," American Economic Review, Vol. 87, No. 2 (May), 164-8.

UNDP (1999), “Human Development Report 1997”, New York: Oxford University Press.

Williamson, John (1990), "What Washington Means by Policy Reform", in John Williamson (ed.), Latin American Adjustment: How Much has Happened? (Washington: Institute for International Economics).

(1997), "The Washington Consensus Revisited", in Louis Emmerij (ed.), Economic and Social Development into the XXI Century (Washington: Inter-American Development Bank).

World Bank (1997), "Global Economic Prospects and the Developing Countries," (Washington: World Bank). 